\title{
BROOKHLVEN
}

NATIONAL LABORATORY

\section{Leaching of Cadmium, Tellurium and Copper from Cadmium Telluride Photovoltaic Modules}

\author{
Progress Report
}

February 3, 2004

W. Wang and V.M. Fthenakis

National Photovoltaic EHS Assistance Center

Environmental Sciences Department

Brookhaven National laboratory

Upton NY 11973

\author{
Brookhaven National Laboratory \\ Upton, New York 11973-5000 \\ Under Contract No. DE-AC02-98CH10886 with the \\ United States Department of Energy
}




\section{DISCLAIMER}

This report was prepared as an account of work sponsored by an agency of the United States Government. Neither the United States Government nor any agency thereof, nor any of their employees, nor any of their contractors, subcontractors or their employees, makes any warranty, express or implied, or assumes any legal liability or responsibility for the accuracy, completeness, or any third party's use or the results of such use of any information, apparatus, product, or process disclosed, or represents that its use would not infringe privately owned rights. Reference herein to any specific commercial product, process, or service by trade name, trademark, manufacturer, or otherwise, does not necessarily constitute or imply its endorsement, recommendation, or favoring by the United States Government or any agency thereof or its contractors or subcontractors. The views and opinions of authors expressed herein do not necessarily state or reflect those of the United States Government or any agency thereof.

\section{FOR UNCLASSIFIED, UNLIMITED STI PRODUCTS}

Available electronically at-

OSTI:

http://www.osti.gov/bridge

Available for a processing fee to U.S. Department of Energy and its contractors, in paper from-

U.S. Department of Energy

Office of Scientific and Technical Information

P.O. Box 62

Oak Ridge, TN 37831

(865) 576-8401

Facsimile: (865) 576-5728

E-mail: reports@adonis.osti.gov

\section{National Technical Information Service (NTIS):}

Available for sale to the public from-

U.S. Department of Commerce

National Technical Information Service

5285 Port Royal Road

Springfield, VA 22131

(800) 553-6847

Facsimile: (703) 605-6900

Online ordering: http://www.ntis.gov/ordering.htm

(9) Printed on recycled paper 


\section{TABLE OF CONTENTS}

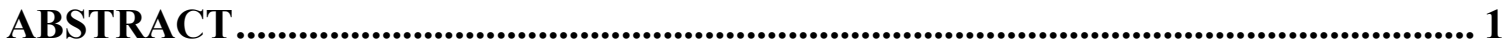

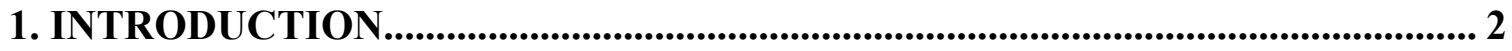

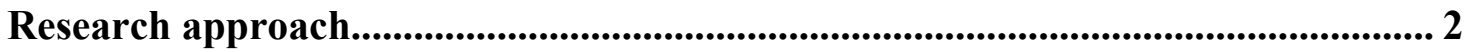

2. DESCRIPTION OF THE EXPERIMENTS ................................................ 2

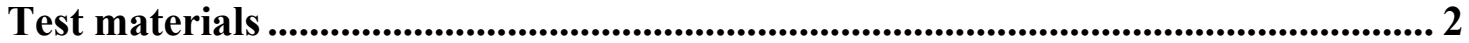

Leaching Equipment................................................................................................. 3

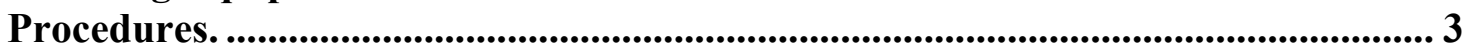

Normalization method for the concentration of leaching solution .......................... 4

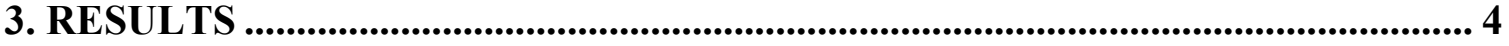

Tests with intact PV glass pieces.............................................................................. 6

Tests with PV fragments ............................................................................... 11

4. UNCERTAINTY ANALYSIS............................................................................. 19

5. CONCLUSION and RECOMMENDATIONS ...................................................... 20

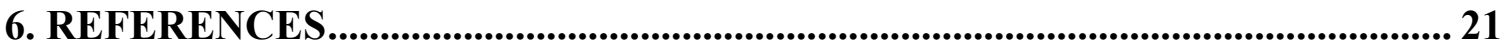




\begin{abstract}
Separating the metals from the glass is the first step in recycling end-of-life cadmium telluride photovoltaic modules and manufacturing scrap. We accomplished this by leaching the metals in solutions of various concentrations of acids and hydrogen peroxide. A relatively dilute solution of sulfuric acid and hydrogen peroxide was found to be most effective for leaching cadmium and tellurium from broken pieces of CdTe PV modules. A solution comprising $5 \mathrm{~mL}$ of hydrogen peroxide per $\mathrm{kg}$ of PV scrap in $1 \mathrm{M}$ sulfuric acid, gave better results than the $12 \mathrm{~mL} \mathrm{H}_{2} \mathrm{O}_{2} / \mathrm{kg}, 3.2 \mathrm{M} \mathrm{H}_{2} \mathrm{SO}_{4}$ solution currently used in the industry. Our study also showed that this dilute solution is more effective than hydrochloric-acid solutions and it can be reused after adding a small amount of hydrogen peroxide. These findings, when implemented in large-scale operation, would result in significant savings due to reductions in volume of the concentrated leaching agents $\left(\mathrm{H}_{2} \mathrm{SO}_{4}\right.$ and $\left.\mathrm{H}_{2} \mathrm{O}_{2}\right)$ and of the alkaline reagents required to neutralize the residuals of leaching.
\end{abstract}




\section{INTRODUCTION}

Supported by the US Department of Energy, Brookhaven National Laboratory (BNL) is undertaking an experimental study on the treatment of CdTe photovoltaic glass waste. The interest in treating the waste streams from environmental concerns that cadmium poses health concerns. The Environmental Protection Agency (EPA) regulates its discharge, and therefore, before disposing of CdTe-bearing PV manufacturing waste or spent PV products, a treatment technology must be identified that meets stringent environmental regulations. Hence, the major objective of this study is to establish a methodology that can prevent any environmental damage caused by cadmium through the disposal of PV product wastes, and can generate environmentally friendly, clean glass. Another objective is to determine a practical and economical technology for recovering and recycling of cadmium and tellurium extracted from the PV modules

Research approach. Very little research data exists on treating CdTe-bearing PV manufacturing wastes [1,2,3]. Thermodynamic information on tellurium [6] and cadmium has shown the following: cadmium is soluble in acid media, and insoluble in neutral and slightly alkaline media; tellurium (IV) is sparingly soluble in acid media, insoluble in neutral media, and soluble in alkaline media; and, tellurium (VI) is soluble in acid media, and insoluble in alkaline media. Other studies show that telluride can be readily oxidized with hydrogen peroxide in acid media [4,5]. Here, our approach is to leach out cadmium and tellurium from CdTe-bearing PV glass using hydrogen peroxide in acid media, followed by electrolysis to separate cadmium from tellurium.

\section{DESCRIPTION OF THE EXPERIMENTS}

Test materials. Two forms of PV product samples were tested in this study: 1) Intact pieces measuring 2.5 " by 12 " cut from CdTe PV modules manufactured by First Solar L.L.C., Perrysburg, Ohio; 2) Various sized fragments of PV modules representative of manufacturing waste in the same facility. These fragments were produced by breaking "out of specs" modules in a hammer-mill. 
The average composition of the metals in the intact pieces (w/o connectors), measured by mass balances in the manufacturing facility, is approximately $0.05 \mathrm{Cd} \mathrm{wt} \% ; 0.06 \% \mathrm{Te}$ wt $\%$; and, $0.01 \mathrm{Cu} \mathrm{wt} \%$.

The composition of the PV module fragments is uncertain since they were produced from "out of specs" modules during the start-up of manufacturing. They were expected to contain, on average, more copper than the intact pieces because they include bus connections and likely were non-homogeneous.

Leaching Equipment. The leaching tests initially were carried out in beakers held in a water bath at a carefully controlled temperature. A mercury thermometer in the leach solution measured the temperature. The leach slurries were agitated by a motor-driven, Teflon-coated stirrer paddle. Samples of the solution were withdrawn periodically with a syringe to assess the leaching rate.

After preliminary tests, the experiments were continued at ambient temperature and more intense agitation. Subsequently, a tumbling machine was used that is designed for Toxicity Characteristic Leaching Procedure (TCLP) tests. PV fragments were mixed with certain amount of leaching agent in a plastic bottle and sealed, and then the bottles were put into the cages of the tumbling machine. Samples were withdrawn every 30 minutes, diluted with $5 \% \mathrm{HNO}_{3}$, and analyzed for cadmium, tellurium, and copper using a Varian Model Liberty 100 Inductively Coupled Plasma (ICP) spectrometer.

In a four tests (\#33 to \#36), a commercial paint-can shaker was used instead of the TCLP tumbler, to see whether the intensity of mixing affected leaching.

Procedures. We assessed the efficiency of two oxidative-leaching procedures in extracting cadmium and tellurium from PV glass; hydrogen peroxide leaching in sulfuric acid, and hydrogen peroxide leaching in hydrochloric acid. These experiments were done at two scales, with $\sim 315 \mathrm{~g}$ of PV glass in small plastic bottles, and $\sim 2153 \mathrm{~g}$ of PV glass in large plastic bottles. The pieces of intact PV glass were first carefully broken into smaller pieces with a hammer, and loaded into a plastic bottle. Fresh acid solutions, i.e., $\mathrm{H}_{2} \mathrm{SO}_{4}$ or $\mathrm{HCl}$, were prepared containing aqueous $\mathrm{H}_{2} \mathrm{O}_{2}(30 \%)$ as an oxidizing agent, and a surfactant, $\mathrm{C}_{8} \mathrm{H}_{17} \mathrm{SO}_{4} \mathrm{Na}$ were added. The concentration of acid ranged from $1.0 \mathrm{M}$ to 4.0 
M. To obtain a complete leaching profile, the tumbling machine was run for 48 hours, although the samples were withdrawn from time to time. The samples were then filtered through syringe filters with the pore size of $0.20 \mu \mathrm{m}$ to $0.70 \mu \mathrm{m}$. The filtrate was diluted with $5 \% \mathrm{HNO}_{3}$ and the solutions were analyzed for cadmium, tellurium, and copper by ICP spectrometry.

Normalization method for the concentration of leaching solution. The concentration measurements from the ICP analysis were normalized to account for the dilution of the sample and depletion of the leaching solution during sampling, and were expressed as wt $\%$ of the PV sample used in each test. The following equation was used to normalize the concentrations of the leaching solutions:

$$
C_{I}^{\text {NORMALIZED }}=C_{I}+\frac{b \times\left(C_{1}+C_{2}+C_{3}+\ldots \ldots+C_{I}-I \times C_{I}\right)}{a_{0}}
$$

in which, $C_{I}^{\text {NORMALIZED }}$ is the normalized concentration of the leaching solution after $I$ sampling;

$C_{I}$ is the measured concentration of the leaching solution after $I$ sampling.

$C_{1}$ is the measured concentration of the leaching solution after the first sampling $C_{2}$ is the measured concentration of the leaching solution after the second sampling.

$b$ is the amount of single sampling in grams

$a_{0}$ is the amount of initial leaching solution in grams

$I$ is $I^{\text {th }}$ sampling.

\section{RESULTS}

The preliminary tests showed that $\mathrm{H}_{2} \mathrm{O}_{2}$ readily oxidized both cadmium and tellurium in acid media. The leaching reactions can be expressed as follows [1,6,7]:

$\mathrm{CdTe}+\mathrm{H}_{2} \mathrm{O}_{2}+\mathrm{H}_{2} \mathrm{SO}_{4}=\mathrm{Cd} \mathrm{SO}_{4}+2 \mathrm{H}_{2} \mathrm{O}+\mathrm{Te}$ 


$$
\begin{aligned}
& \mathrm{Te}+2 \mathrm{H}_{2} \mathrm{O}_{2}+2 \mathrm{H}_{2} \mathrm{SO}_{4}=4 \mathrm{H}_{2} \mathrm{O}+\mathrm{Te}^{+4}+2 \mathrm{SO}_{4}{ }^{-2} \text {. } \\
& \mathrm{CdS}+\mathrm{H}_{2} \mathrm{O}_{2}+\mathrm{H}_{2} \mathrm{SO}_{4}=\mathrm{CdSO} 4+2 \mathrm{H}_{2} \mathrm{O}+\mathrm{S} \text {. } \\
& \mathrm{CdTe}+\mathrm{H}_{2} \mathrm{O}_{2}+2 \mathrm{HCl}=\mathrm{Cd} \mathrm{Cl}_{2}+2 \mathrm{H}_{2} \mathrm{O}+\mathrm{Te} . \\
& \mathrm{Te}+2 \mathrm{H}_{2} \mathrm{O}_{2}+4 \mathrm{HCl}=4 \mathrm{H}_{2} \mathrm{O}+\mathrm{Te}^{+4}+4 \mathrm{Cl}^{-} \text {. . } \\
& \mathrm{CdS}+\mathrm{H}_{2} \mathrm{O}_{2}+2 \mathrm{HCl}=\mathrm{Cd} \mathrm{Cl}_{2}+2 \mathrm{H}_{2} \mathrm{O}+\mathrm{S} \text {. } \\
& \mathrm{Cu}+\mathrm{H}_{2} \mathrm{O}_{2}+\mathrm{H}_{2} \mathrm{SO}_{4}=\mathrm{Cu} \mathrm{SO}+2 \mathrm{H}_{2} \mathrm{O} \\
& \mathrm{CdS}+\mathrm{CuSO}_{4}=\mathrm{CdSO}_{4}+\mathrm{CuS} \downarrow \\
& \mathrm{CdS}+\mathrm{H}_{2} \mathrm{SO}_{4}=\mathrm{CdSO}_{4}+\mathrm{H}_{2} \mathrm{~S} \uparrow
\end{aligned}
$$

The major parameters describing these tests are summarized in Table 1, below. 


\begin{tabular}{|c|c|c|c|c|c|}
\hline \multicolumn{6}{|c|}{ "TABLE 1. EXPERIMENTAL PARAMETERS } \\
\hline \multirow{2}{*}{ Test } & \multirow{2}{*}{ Raw material } & \multirow{2}{*}{$\begin{array}{l}\text { Leaching } \\
\text { acid and } \\
\text { concentration }\end{array}$} & \multirow{2}{*}{\begin{tabular}{|} 
Oxidizing agent \\
mL- $\mathrm{H}_{2} \mathrm{O}_{2} /$ kg-glass \\
$(\mathrm{RO})$
\end{tabular}} & \multicolumn{2}{|c|}{ Ratio of liquid to glass ${ }^{+}$} \\
\hline & & & & $\begin{array}{c}\text { kg-liquid/kg-glass } \\
(\mathrm{R})\end{array}$ & mL-liquid/kg-glass \\
\hline$\# 11$ & intact PV module & $4.0 \mathrm{M} \mathrm{HCl}$ & 12.6 & 0.54 & 473 \\
\hline$\# 12$ & intact PV module & $2.0 \mathrm{M} \mathrm{HCl}$ & 12.6 & 0.54 & 473 \\
\hline$\# 13$ & intact PV module & $1.0 \mathrm{M} \mathrm{HCl}$ & 12.7 & 0.51 & 474 \\
\hline$\# 14$ & intact PV module & $4.0 \mathrm{M} \mathrm{H}_{2} \mathrm{SO}_{4}$ & 12.7 & 0.62 & 476 \\
\hline$\# 15$ & intact PV module & $2.0 \mathrm{M} \mathrm{H}_{2} \mathrm{SO}_{4}$ & 12.8 & 0.59 & 478 \\
\hline$\# 16$ & intact PV module & $1.0 \mathrm{M} \mathrm{H}_{2} \mathrm{SO}_{4}$ & 12.8 & 0.55 & 480 \\
\hline$\# 17$ & intact PV module & $1.0 \mathrm{M} \mathrm{HCl}$ & 4.7 & 0.53 & 475 \\
\hline$\# 18$ & intact PV module & $1.0 \mathrm{M} \mathrm{HCl}$ & 8.0 & 0.53 & 479 \\
\hline$\# 19$ & intact PV module & $1.0 \mathrm{M} \mathrm{H}_{2} \mathrm{SO}_{4}$ & 4.8 & 0.55 & 484 \\
\hline$\# 20$ & intact PV module & $1.0 \mathrm{M} \mathrm{H}_{2} \mathrm{SO}_{4}$ & 7.9 & 0.57 & 476 \\
\hline \#21. & PV module fragments & $2.0 \mathrm{M} \mathrm{H}_{2} \mathrm{SO}_{4}$ & 12.5 & 0.50 & 479 \\
\hline$\# 22$ & PV module fragments & $1.0 \mathrm{M} \mathrm{H}_{2} \mathrm{SO}_{4}$ & 12.5 & 0.49 & 479 \\
\hline$\# 23$ & intact PV module & 1.0 $\mathrm{M} \mathrm{H}_{2} \mathrm{SO}_{4}$, used* & 12.8 & 0.61 & 532 \\
\hline$\# 24$ & intact PV module & $1.0 \mathrm{M} \mathrm{H}_{2} \mathrm{SO}_{4}$, used* & 6.3 & 0.61 & 524 \\
\hline \#25 & PV module fragments & $2.0 \mathrm{M} \mathrm{H}_{2} \mathrm{SO}_{4}$ & 7.9 & 0.53 & 501 \\
\hline$\# 26$ & PV module fragments & $1.0 \mathrm{M} \mathrm{H}_{2} \mathrm{SO}_{4}$ & 7.9 & 0.51 & 481 \\
\hline$\# 27$ & intact PV module & 1.0 $\mathrm{M} \mathrm{H}_{2} \mathrm{SO}_{4}$, used $2 \mathrm{x}^{*}$ & 6.4 & 0.82 & 709 \\
\hline$\# 28$ & PV module fragments & $3.2 \mathrm{M} \mathrm{H}_{2} \mathrm{SO}_{4}$ & 12.0 & 0.27 & 231 \\
\hline$\# 29$ & PV module fragments & $2.0 \mathrm{M} \mathrm{H}_{2} \mathrm{SO}_{4}$ & 11.5 & 0.26 & 235 \\
\hline$\# 30$ & PV module fragments & $2.0 \mathrm{M} \mathrm{H}_{2} \mathrm{SO}_{4}$ & 5.7 & 0.25 & 228 \\
\hline \#31 & PV module fragments & $1.0 \mathrm{M} \mathrm{H}_{2} \mathrm{SO}_{4}$ & 11.4 & 0.24 & 234 \\
\hline \#32 & PV module fragments & $1.0 \mathrm{M} \mathrm{H}_{2} \mathrm{SO}_{4}$ & 5.7 & 0.24 & 228 \\
\hline \#33 & PV module fragments & $3.2 \mathrm{M} \mathrm{H}_{2} \mathrm{SO}_{4}$ & 12.0 & 0.27 & 231 \\
\hline \#34 & PV module fragments & $2.0 \mathrm{M} \mathrm{H}_{2} \mathrm{SO}_{4}$ & 11.4 & 0.26 & 234 \\
\hline \#35 & PV module fragments & $2.0 \mathrm{M} \mathrm{H}_{2} \mathrm{SO}_{4}$ & 5.7 & 0.25 & 228 \\
\hline \#36 & PV module fragments & $1.0 \mathrm{M} \mathrm{H}_{2} \mathrm{SO}_{4}$ & 11.4 & 0.24 & 234 \\
\hline \#37 & PV module fragments & $1.0 \mathrm{M} \mathrm{H}_{2} \mathrm{SO}_{4}$ & 5.7 & 0.24 & 228 \\
\hline \#38 & PV module fragments & $1.0 \mathrm{M} \mathrm{H}_{2} \mathrm{SO}_{4}$ & 11.5 & 0.51 & 488 \\
\hline
\end{tabular}

" "glass" denotes the entire PV module pieces, which comprise about 99\% glass.

* "Used" means used once before

"Used $2 \mathrm{x}$ " means used two times before

Tests with intact PV glass pieces. Leaching of intact PV glass pieces was tested with different sulfuric acid/hydrogen peroxide and hydrochloric acid/ hydrogen peroxide solutions. Our experiments showed that, at the same strength, sulfuric acid extracted 
somewhat more cadmium and tellurium. Figures 1 and 2, respectively, show the first four hours' extraction profiles for Cd and Te (tests \# 11-20). .

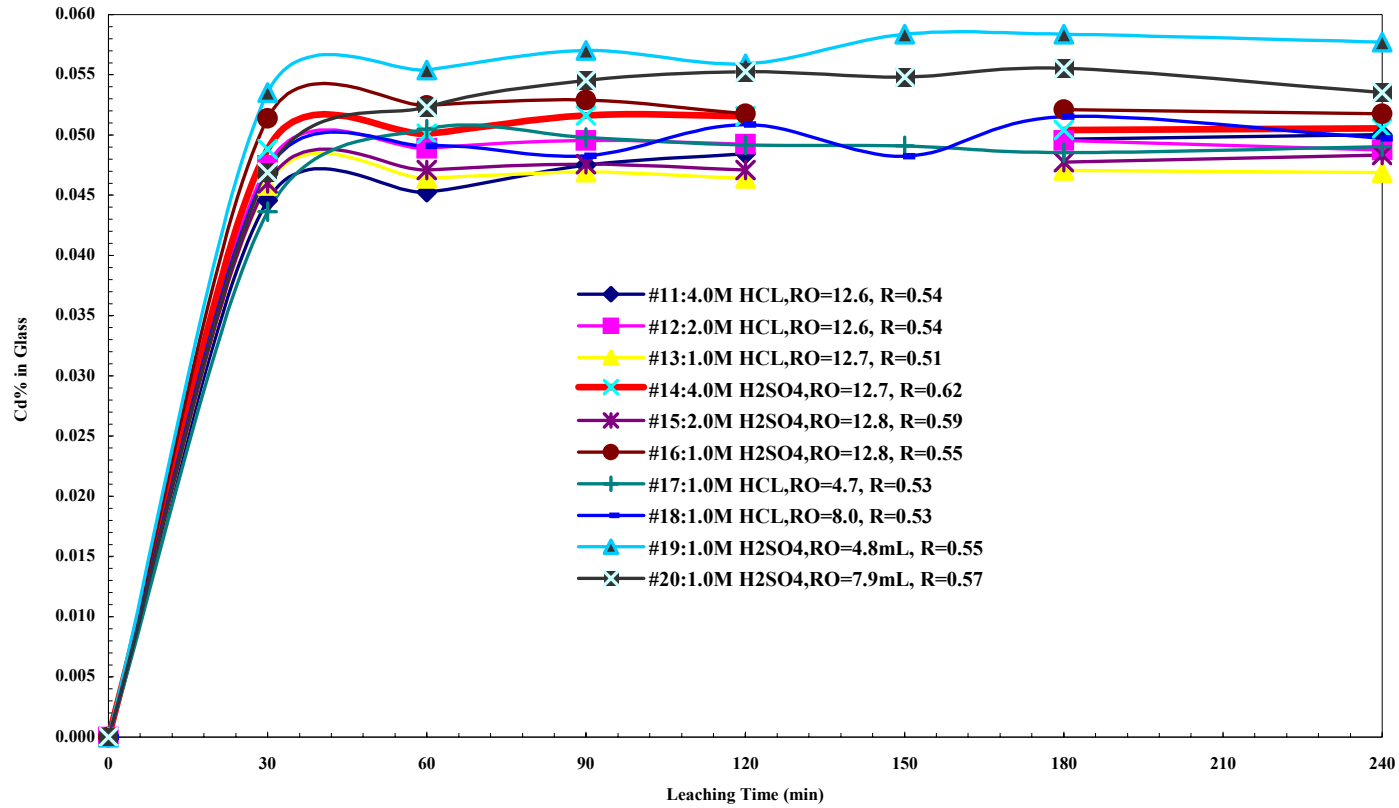

Figure 1. Cd Leaching Experiments \#11-\#20. RO-ratio of $\mathrm{H}_{2} \mathrm{O}_{2}$ to glass(mL/kg); Rratio of leaching solution to glass $(\mathrm{kg} / \mathrm{kg})$ 


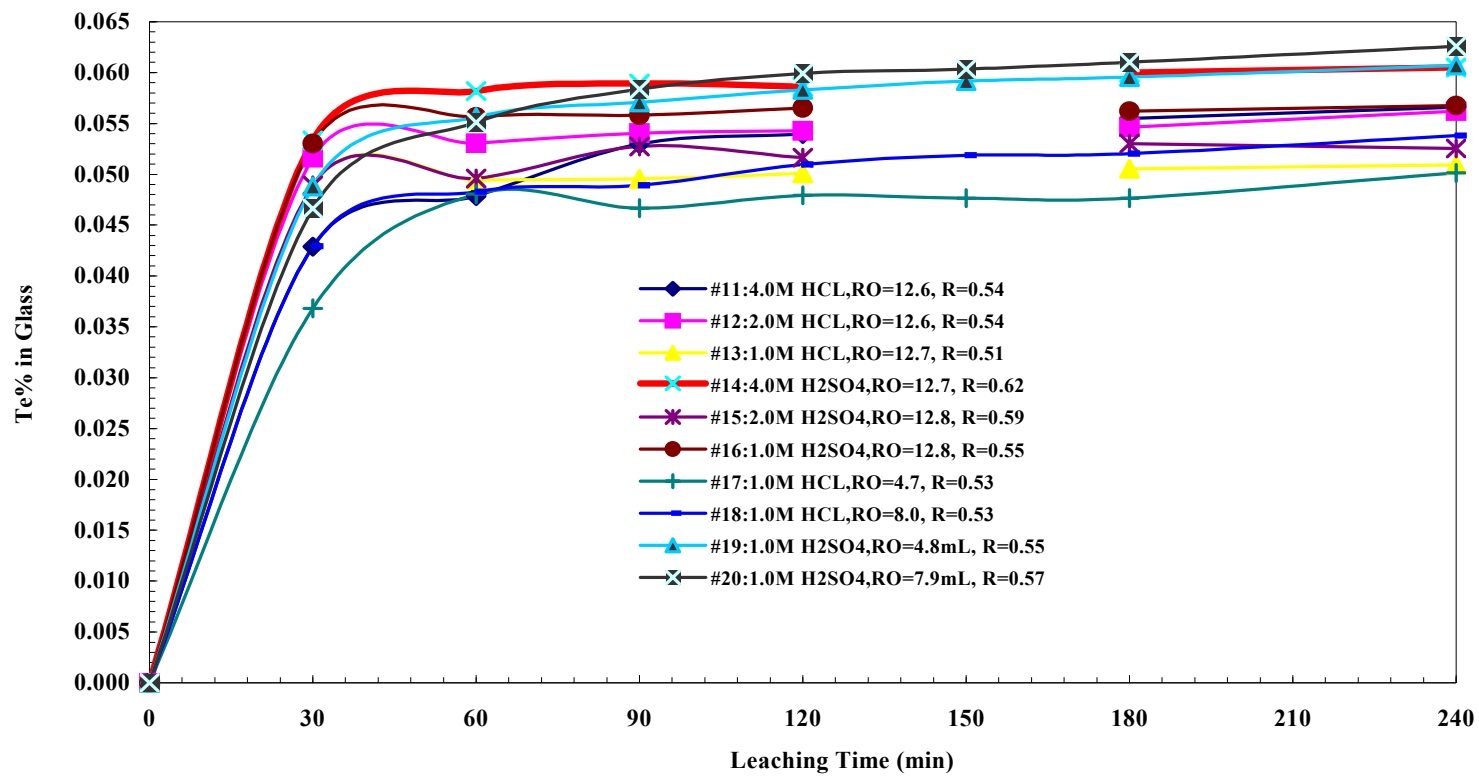

Figure 2. Te Leaching Experiments \#11-\#20. RO-ratio of $\mathrm{H}_{2} \mathrm{O}_{2}$ to glass(mL/kg); Rratio of leaching solution to glass $(\mathrm{kg} / \mathrm{kg})$

Figures 1 and 2 show that the sulfuric acid-based tests \#16, \#19, and \#20 best leached Cd. The liquid/ glass ratios of these tests $(\mathrm{R})$ were around $\sim 0.54 \mathrm{~kg}$ liquid per $\mathrm{kg}$ glass $(\sim 480$ $\mathrm{mL}-$ liquid/kg-glass); the ratios of hydrogen peroxide (RO) added to the leaching agent, 1.0M sulfuric acid, were $12.8,4.8$, and $7.9 \mathrm{~mL}-\mathrm{H}_{2} \mathrm{O}_{2} / \mathrm{kg}$-glass for tests $\# 16$, \#19, and \#20, respectively. This suggests that a higher strength acid may not be advantageous for leaching cadmium as anticipated. Most of the tests revealed that in the first 30 minutes, cadmium was more readily attacked and leached out into solution than tellurium. Thus, at the 30 -minute point, more than $80 \%$ of cadmium and tellurium were transferred from the glass into solution. However, stronger sulfuric acid initially appears to leach $\mathrm{Te}$ quicker than a weaker solution, as shown in Figure 2. During the first 90 minutes, the leaching of tellurium with $4.0 \mathrm{M}$ of sulfuric acid was the highest among all tests, but with longer times (i.e., $>2 \mathrm{hr}$ ) the $1 \mathrm{M}$ acidic solution became equally effective as the $4 \mathrm{M}$ one. No further studies were made of hydrochloric acid leaching because its efficacy at extracting cadmium and tellurium was poorer than that of sulfuric acid, and furthermore, hydrochloric acid is more volatile. We note that ICP analysis of the solutions showed 
that trace amounts of copper exists in intact PV glass. The extraction of copper was quantified in later tests.

The efficiency of reused sulfuric acid also was tested to assess the possibility of recycling the leaching agent. These results are shown in tests \#23,\#24, and \#27. The first two solutions were obtained by mixing the filtered used solutions from tests \#16, \#19, and $\# 20$, and adding a small amount of make-up $\mathrm{H}_{2} \mathrm{O}_{2}$. (The amount of hydrogen peroxide added to \#23 and \#24 differed, as seen from Table 1). In Test \#27 the leaching solution already was used twice; it was a mixture of the filtrate from \#23 and \#24. Figures 3 and 4 reveal that the reused solutions were slightly less effective than unused ones. A onceused solution was about 10\% less effective than the original in leaching $\mathrm{Cd}$, and $3 \%$ less effective in leaching Te. The twice-used solution was about $15 \%$ less effective in leaching both metals. Nevertheless, these results demonstrate that leaching solutions can be reused after adding the appropriate makeupH2O2, thereby minimizing the production of liquid waste. The measured concentrations of reused leaching solutions are listed in Table 2.

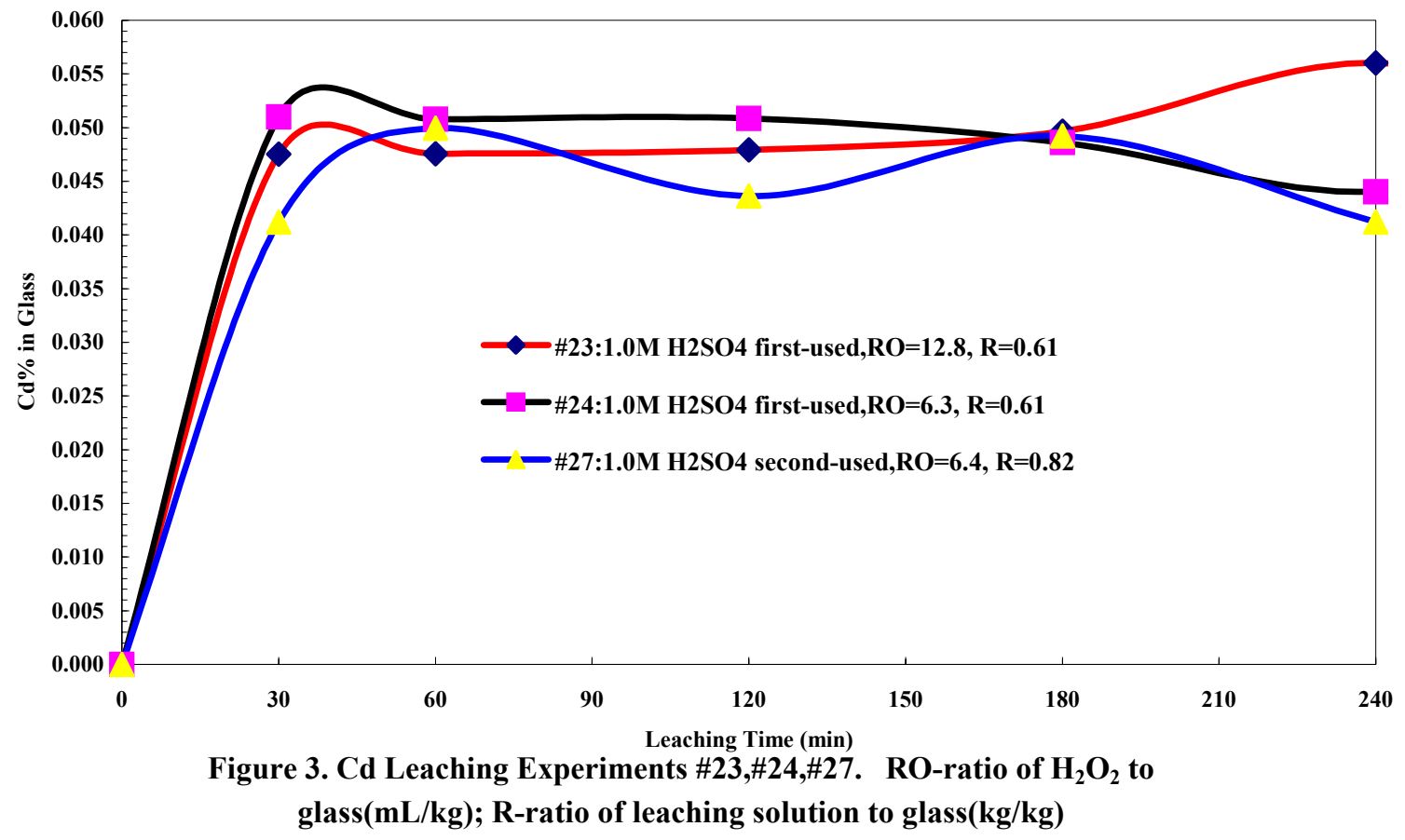




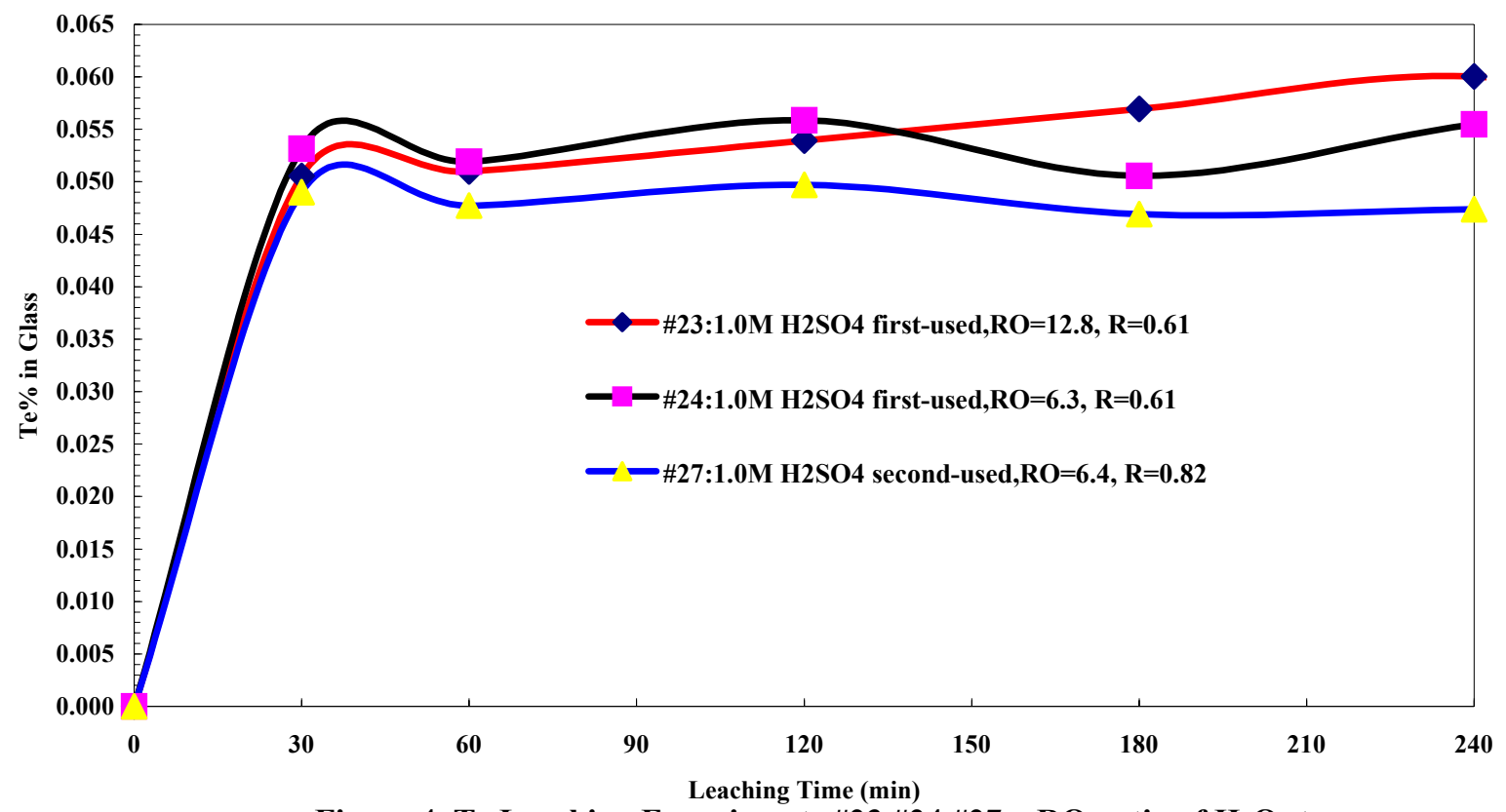

Figure 4. Te Leaching Experiments \#23,\#24,\#27. RO-ratio of $\mathrm{H}_{2} \mathrm{O}_{2}$ to glass(mL/kg); R-ratio of leaching solution to glass $(\mathrm{kg} / \mathrm{kg})$

Table 2. The Concentration of Reused Leaching Agent

\begin{tabular}{|c|c|c|c|c|c|c|}
\hline \multirow{3}{*}{$\frac{\text { Leaching }}{\text { Time }}$} & \multicolumn{2}{|c|}{ \#23 Normalized Results } & \multicolumn{2}{|c|}{ \#24 Normalized Results } & \multicolumn{2}{|c|}{ \#27 Normalized Results } \\
\hline & \multicolumn{2}{|c|}{$1.0 \mathrm{M} \mathrm{H}_{2} \mathrm{SO}_{4}$ re-used, $\mathrm{RO}=12.8$} & \multicolumn{2}{|c|}{ 1.0 $\mathrm{M} \mathrm{H}_{2} \mathrm{SO}_{4}$ re-used, $\mathrm{RO}=\mathrm{H}_{2} \mathrm{O}_{2}$} & \multicolumn{2}{|c|}{$1.0 \mathrm{M} \mathrm{H}_{2} \mathrm{SO}_{4}$ Re-used $2 \mathrm{x}, \mathrm{RO}=6.4$} \\
\hline & PPM & PPM & PPM & PPM & PPM & PPM \\
\hline$(\min )$ & $\mathrm{Te}$ & $\mathrm{Cd}$ & $\mathrm{Te}$ & $\mathrm{Cd}$ & $\mathrm{Te}$ & $\mathrm{Cd}$ \\
\hline 0 (Initial) & 1080.31 & 979.54 & 1080.31 & 979.54 & 1998.84 & 1759.63 \\
\hline 30 & 1904.40 & 1753.93 & 1953.20 & 1816.94 & 2598.00 & 2263.59 \\
\hline 60 & 1910.84 & 1754.39 & 1932.38 & 1813.00 & 2582.73 & 2370.52 \\
\hline 120 & 1959.33 & 1760.59 & 1997.59 & 1814.33 & 2606.88 & 2293.07 \\
\hline 180 & 2061.51 & 1830.80 & 1977.07 & 1748.96 & 2572.48 & 2361.45 \\
\hline 240 & 2106.09 & 1891.08 & 2007.19 & 1799.88 & 2578.12 & 2263.50 \\
\hline 300 & 1964.72 & 1770.25 & 2047.31 & 1811.45 & & \\
\hline 420 & & & & & 2547.00 & 2215.31 \\
\hline 1080 & 2108.77 & 1867.85 & 2115.57 & 1828.44 & & \\
\hline 1440 & 2089.08 & 1892.95 & 2009.78 & 1804.56 & 2539.65 & 2222.82 \\
\hline 2880 & & & & & 2674.41 & 2322.94 \\
\hline
\end{tabular}


As shown in Table 2, after two consecutive leaching procedures, the solution contained $\sim 2.5 \mathrm{~g} / \mathrm{L}$ of tellurium and $\sim 2.2 \mathrm{~g} / \mathrm{L}$ of cadmium.

Tests with PV fragments. The PV fragments contained copper in bus connections and in the CdTe layer. Therefore, we also analyzed the leaching solution for copper using ICP. The copper was in elemental form, and, consequently, consumed hydrogen peroxide during leaching, as shown in Reaction 7, and accordingly made it necessary to add $\mathrm{H}_{2} \mathrm{O}_{2}$ makeup solution. In these experiments we also examined the effect of varying the volume of leaching solution used for treating a constant mass of PV fragments. In one series of tests (\#21, \#22, \#25, and \#26), the ratio of liquid to solid was fixed around 480 $\mathrm{mL}-$ liquid/kg-solid (i.e., $0.5 \mathrm{~kg}$-liquid/kg-solid). In other tests (\#28 through \#32), the ratio was around $\sim 230 \mathrm{~mL}$-liquid/kg-glass (i.e., $0.25 \mathrm{~kg}$-liquid/kg-solid).

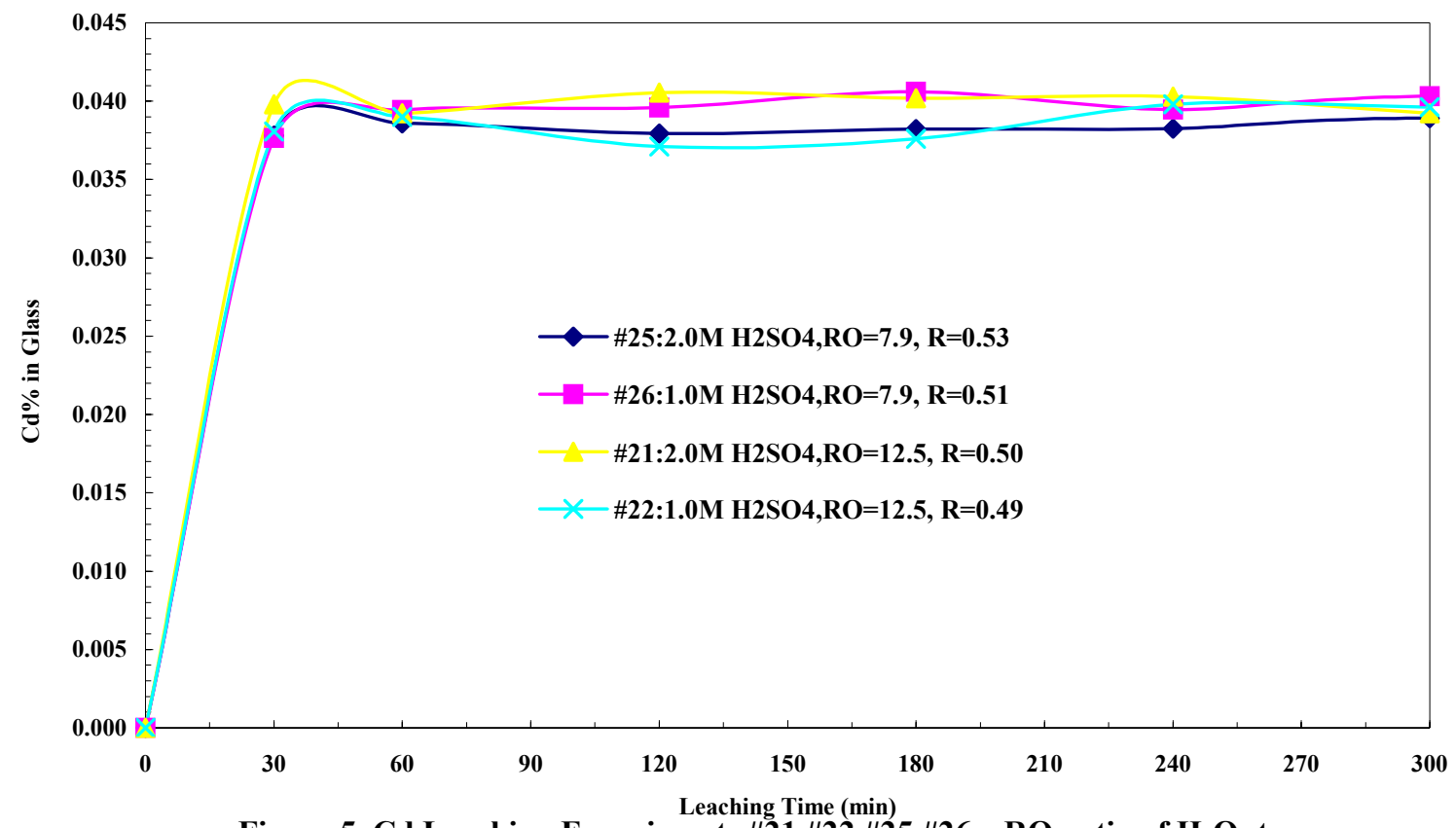

Figure 5. Cd Leaching Experiments \#21,\#22,\#25,\#26. RO-ratio of $\mathrm{H}_{2} \mathrm{O}_{2}$ to glass(mL/kg); R-ratio of leaching solution to glass $(\mathrm{kg} / \mathrm{kg})$ 


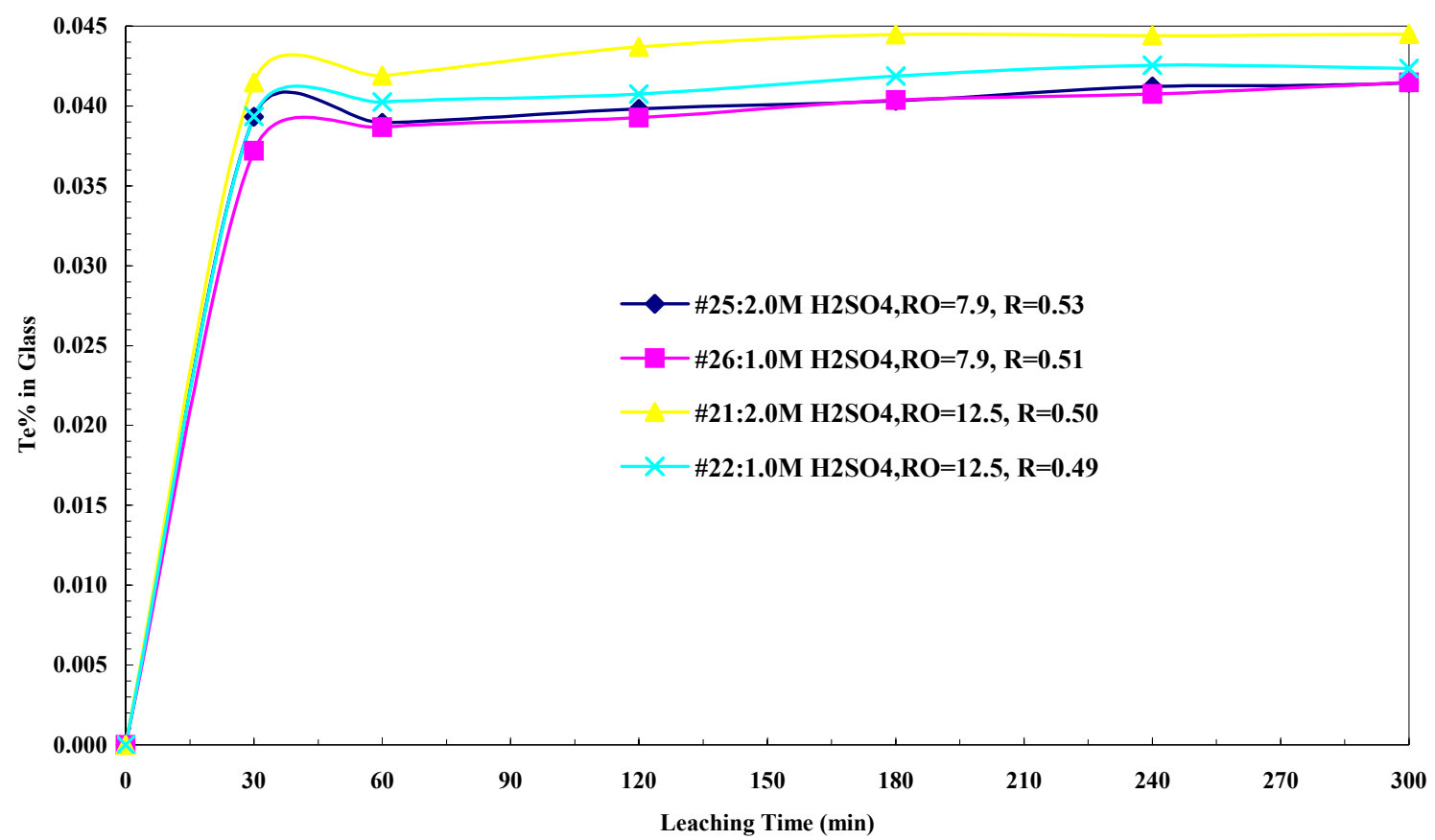

Figure 6. Te Leaching Experiments \#21,\#22,\#25,\#26. RO-ratio of $\mathrm{H}_{2} \mathrm{O}_{2}$ to glass(mL/kg); R-ratio of leaching solution to glass $(\mathrm{kg} / \mathrm{kg})$

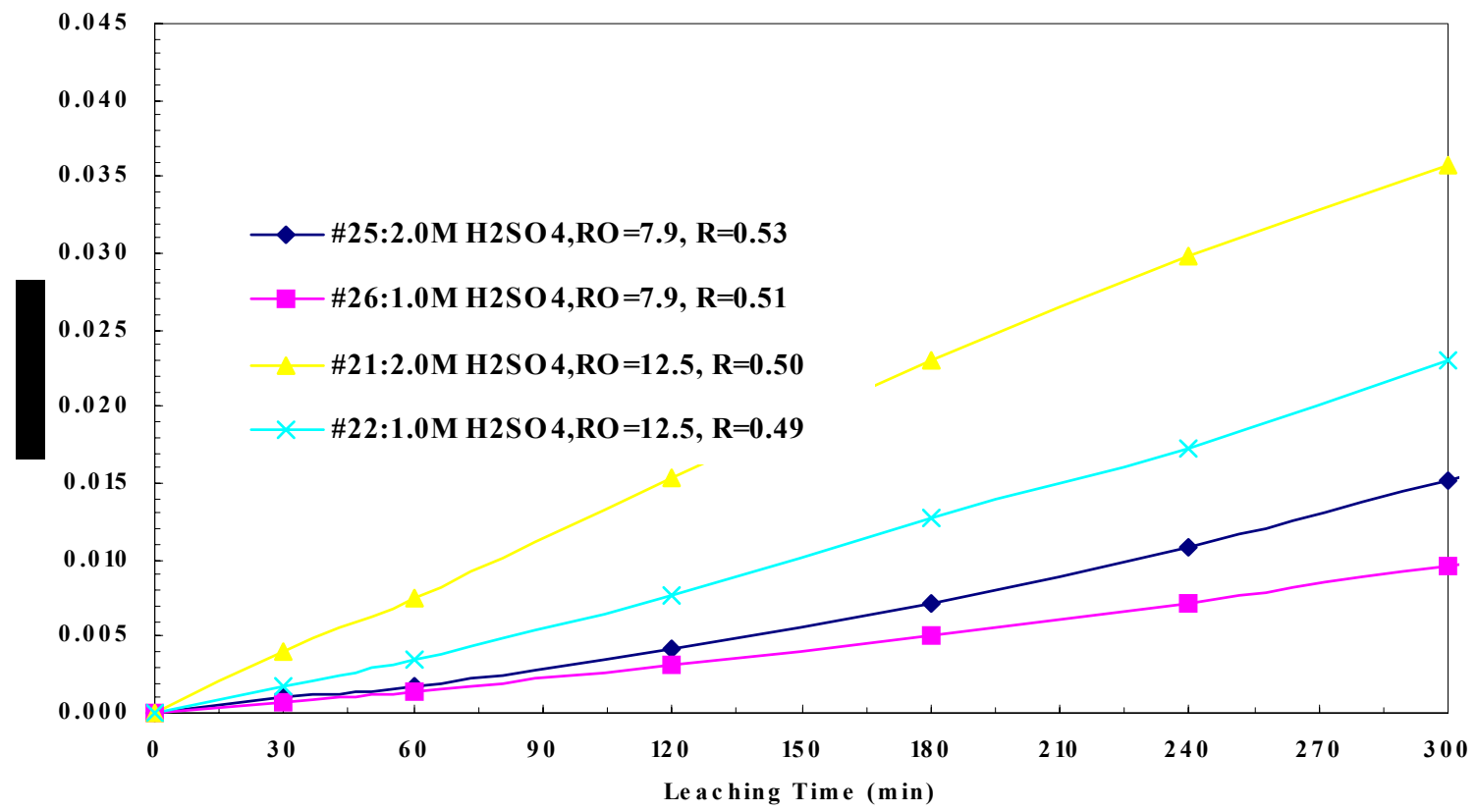

Figure 7. Cu Leaching Experiments \#21,\#22,\#25,\#26. RO-ratio of $\mathrm{H}_{2} \mathrm{O}_{2}$ to glass(mL/kg); R-ratio of leaching solution to glass $(\mathrm{kg} / \mathrm{kg})$ 
Figures 5, 6, and 7, respectively, depict the dissolution of cadmium, tellurium, and copper as function of processing time with the liquid/solid ratio of $\sim 0.5 \mathrm{~kg}-\mathrm{liquid} / \mathrm{kg}-\mathrm{PV}$ fragments. As shown in Figures 5 and 6, the concentration of cadmium and tellurium in solution does not change appreciably after 30 minutes, suggesting that their leaching was completed within this interval. However, the dissolution of copper increases linearly with within the first 300 minutes (Figure 7), and apparently, was not complete by then. In terms of the percentage of tellurium extracted, $2.0 \mathrm{M}$ of sulfuric acid with $12.5 \mathrm{~mL}$ $\mathrm{H}_{2} \mathrm{O}_{2} / \mathrm{kg}$-glass appears to be the best among the four tests. For extraction of cadmium 2.0 $\mathrm{M}$ of sulfuric acid seems to be not much better than $1.0 \mathrm{M}$ of sulfuric acid. More tests are needed, based on intact, uniform concentration PV samples, to confirm this observation. Should this be the case, the weaker acid would be preferred because of its advantages in cost, safety, and waste reduction. Comparison of Figures 1 and 2 with Figures 5 and 6, respectively, shows that the percentage of cadmium and tellurium extracted from intact PV pieces is considerably higher than that extracted from the PV fragments. This is not surprising, given the expected variability in concentrations in the large quantity (400 lb, 55-gal drum) of PV fragments supplied.

The liquid/solid ratio of $\sim 230 \mathrm{~mL}-$ liquid/kg-glass also was explored in tests \#28 through 32. These tests used one-half the solution-to-glass ratio ( $R$ ) than the previous ones. Due to the low ratio of liquid/solid, withdrawing samples from these solutions was almost impossible in the first 300 minutes since very little free liquid phase was created. Therefore, the first sample was taken after 300 minutes of continuous leaching. The results are shown in Figures 8, 9 and 10 respectively. 


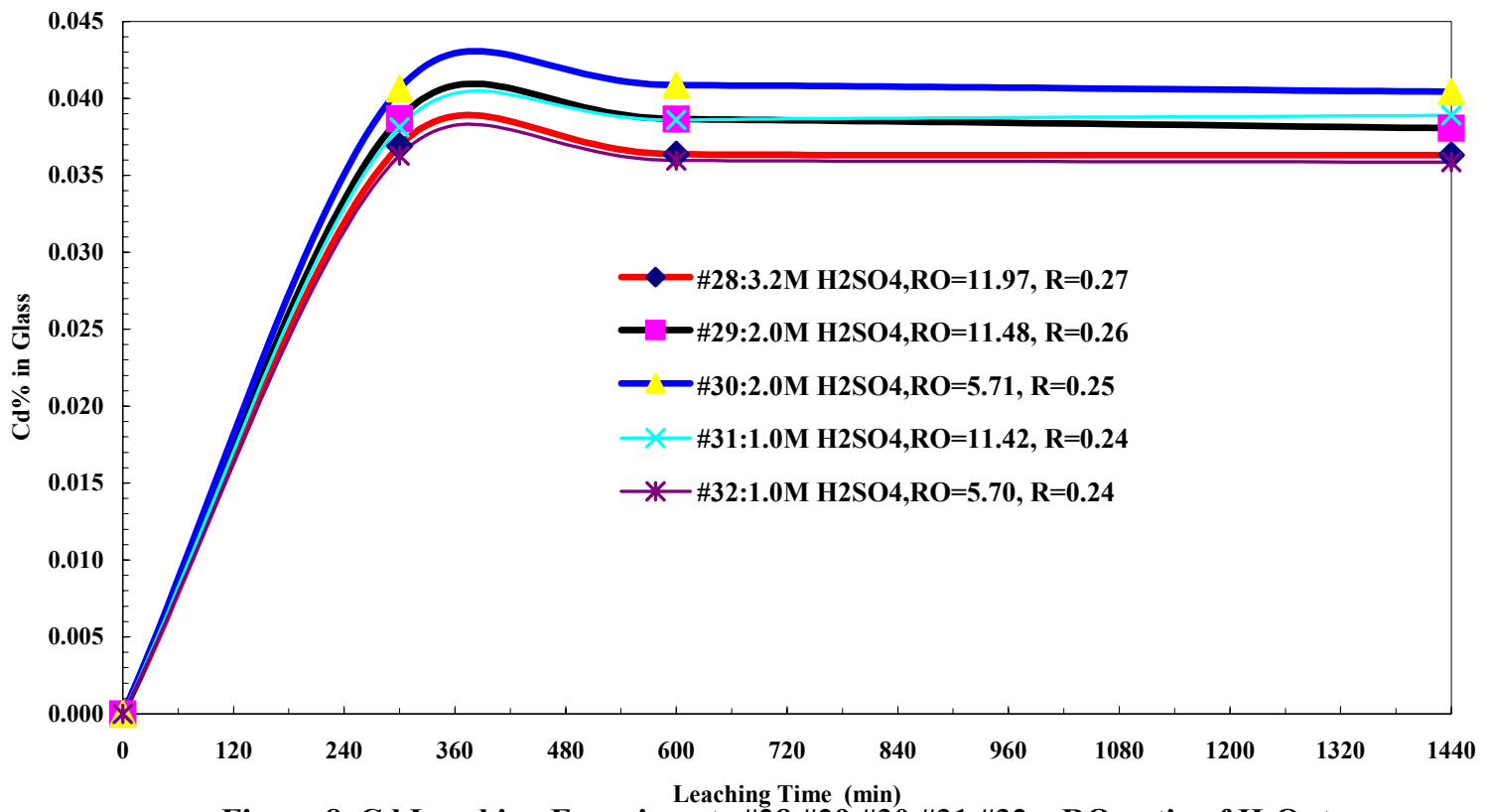

Figure 8. Cd Leaching Experiments \#28,\#29,\#30,\#31,\#32. RO-ratio of $\mathrm{H}_{2} \mathrm{O}_{2}$ to glass(mL/kg); R-ratio of leaching solution to glass $(\mathrm{kg} / \mathrm{kg})$

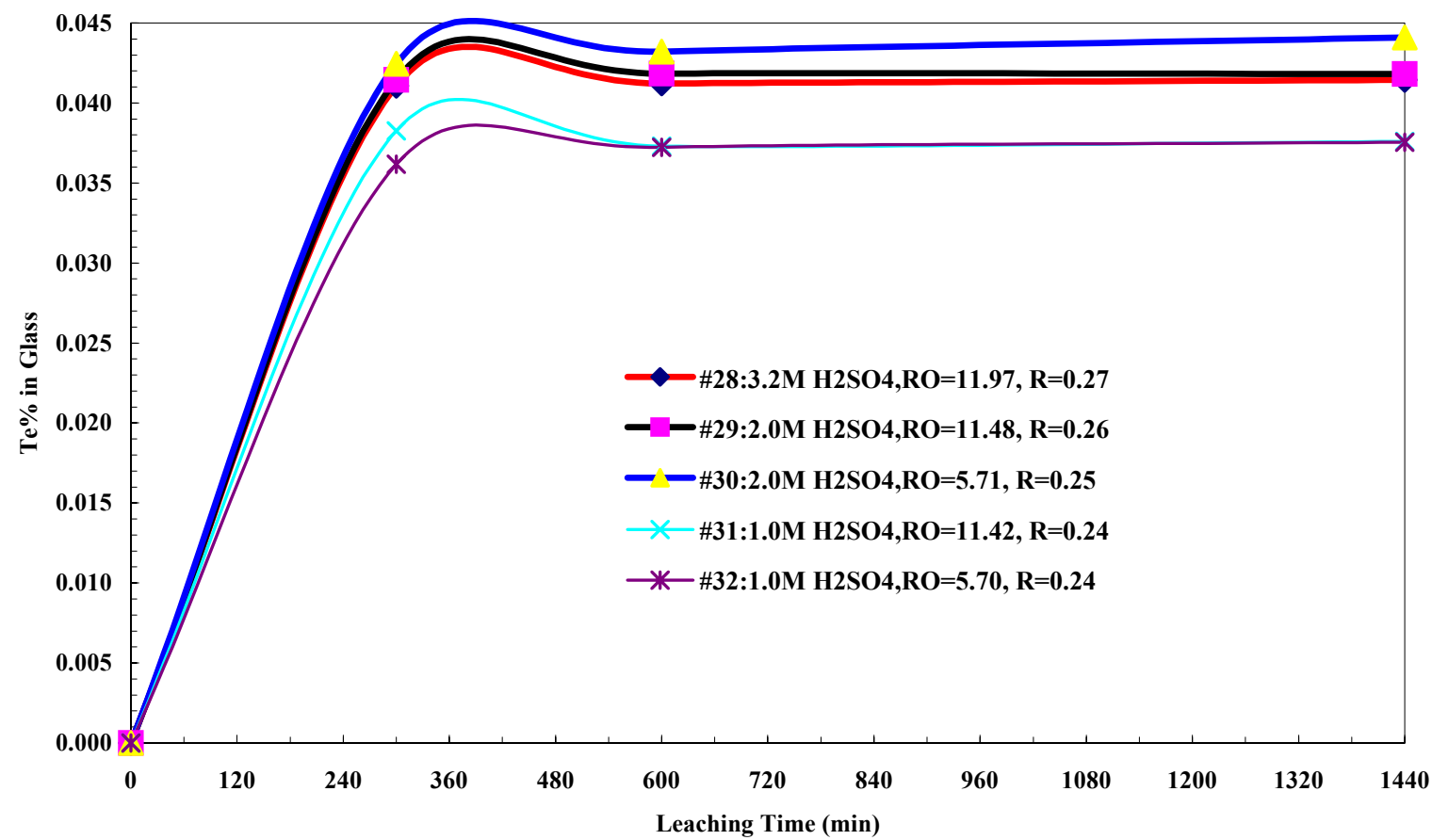

Figure 9. Te Leaching Experiments \#28,\#29,\#30,\#31,\#32. RO-ratio of $\mathrm{H}_{2} \mathrm{O}_{2}$ to glass(mL/kg); R-ratio of leaching solution to glass $(\mathrm{kg} / \mathrm{kg})$ 


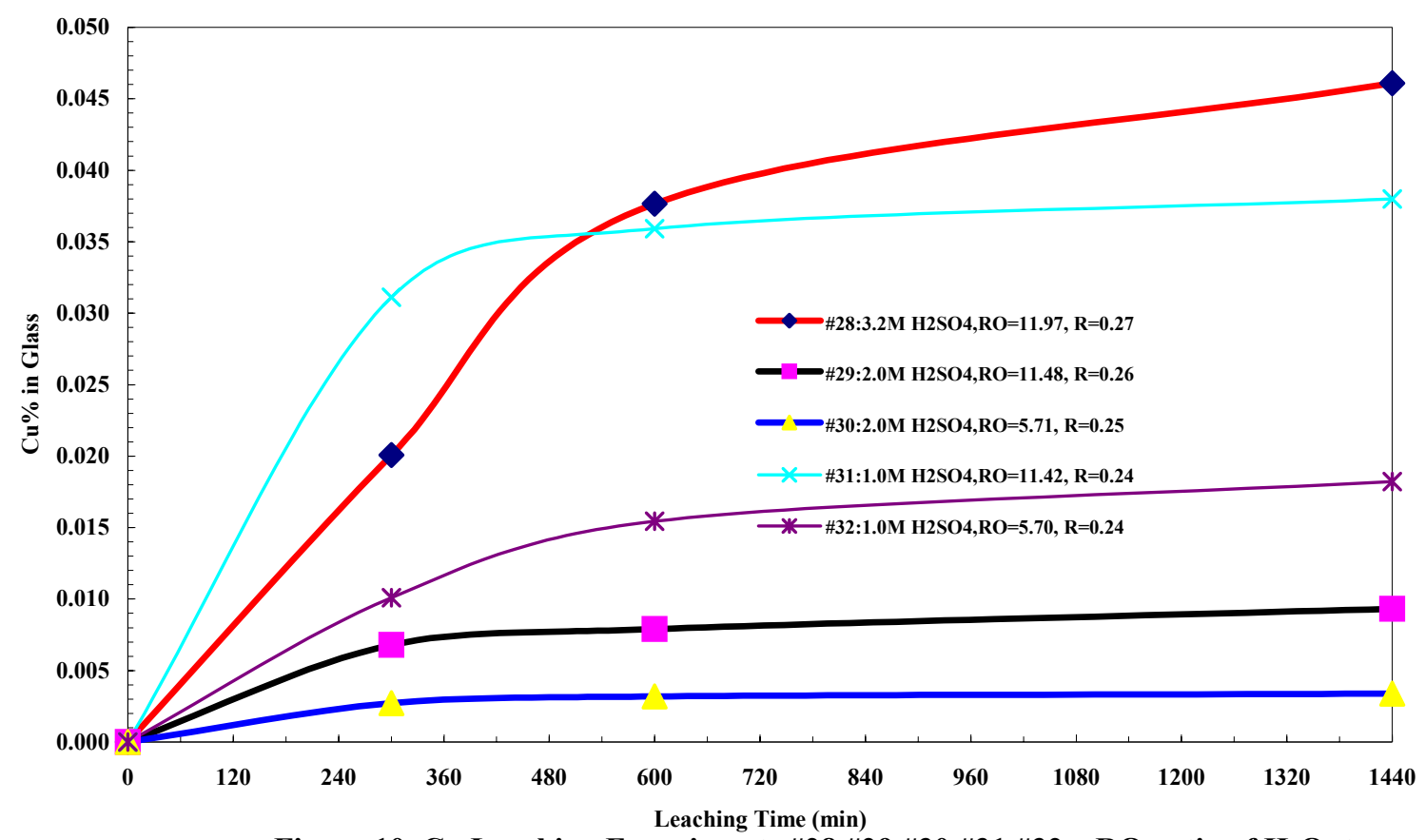

Figure 10. Cu Leaching Experiments \#28,\#29,\#30,\#31,\#32. RO-ratio of $\mathrm{H}_{2} \mathrm{O}_{2}$ to $\operatorname{glass}(\mathrm{mL} / \mathrm{kg})$; R-ratio of leaching solution to glass $(\mathrm{kg} / \mathrm{kg})$

Tests with the low ratio of liquid/solid showed that $2.0 \mathrm{M}$ of sulfuric acid was better than 1.0 M sulfuric acid in extracting tellurium. The best leaching agent for cadmium was 2.0 $\mathrm{M}$ of sulfuric acid and $5.7 \mathrm{~mL}-\mathrm{H}_{2} \mathrm{O}_{2} / \mathrm{kg}$-glass. The percentage of cadmium in PV glass ranges from $0.036 \%$ to $0.041 \%$ and tellurium from $0.036 \%$ to $0.044 \%$.

As in the previous experiments, copper was leached much slower than cadmium and tellurium, and it was not completed within the leaching times we employed. We note, however, than the concentration of copper in the module is much lower than all applicable waste-classification standards, including the California TTLC. The latter and the concentration of $\mathrm{Cu}$ and $\mathrm{Cd}$ in the $\mathrm{CdTe} \mathrm{PV}$ module are shown below.

\begin{tabular}{|c|c|l|}
\hline Element & California TTLC (g/kg) & Module Content (g/kg) \\
\hline $\mathrm{Cu}$ & 2.5 & $0.57\left(\right.$ including both $\mathrm{CuCl}_{2}$ and $\mathrm{Cu}$ foil connections) \\
\hline $\mathrm{Cd}$ & 0.1 & 0.69 \\
\hline
\end{tabular}

Figures 11,12, and 13 plot the results of leaching tests with a commercial paint-can shaker (\#s 33-38). The leaching time for each test was five hours during which three samples were taken for ICP analysis of cadmium, tellurium, and copper. 


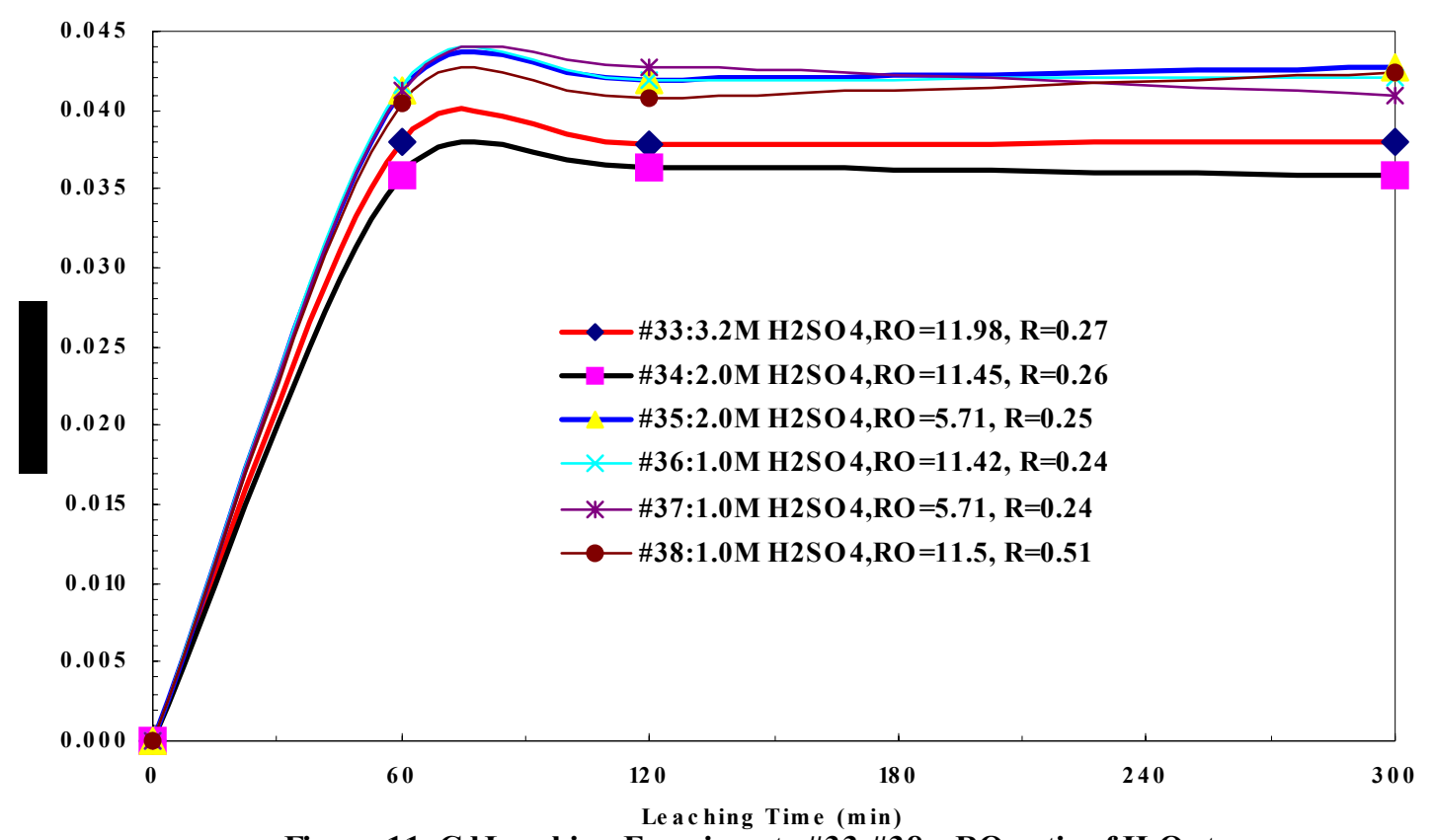

Figure 11. Cd Leaching Experiments \#33-\#38. RO-ratio of $\mathrm{H}_{2} \mathrm{O}_{2}$ to glass (mL/kg); R-ratio of leaching solution to glass $(\mathrm{kg} / \mathrm{kg})$

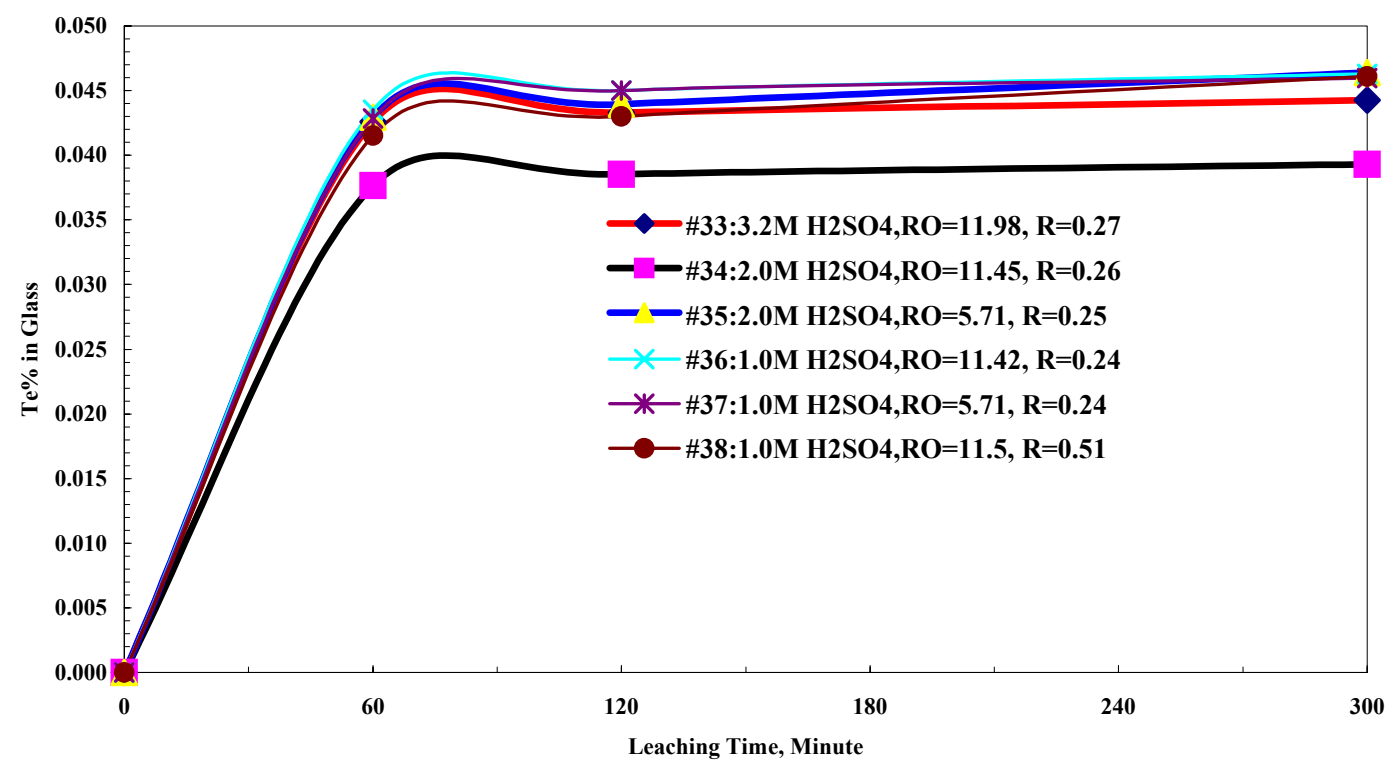

Figure 12. Te Leaching Experiments \#33-\#38. RO-ratio of $\mathrm{H}_{2} \mathrm{O}_{2}$ to glass $(\mathrm{mL} / \mathrm{kg})$; Rratio of leaching solution to glass $(\mathrm{kg} / \mathrm{kg})$ 


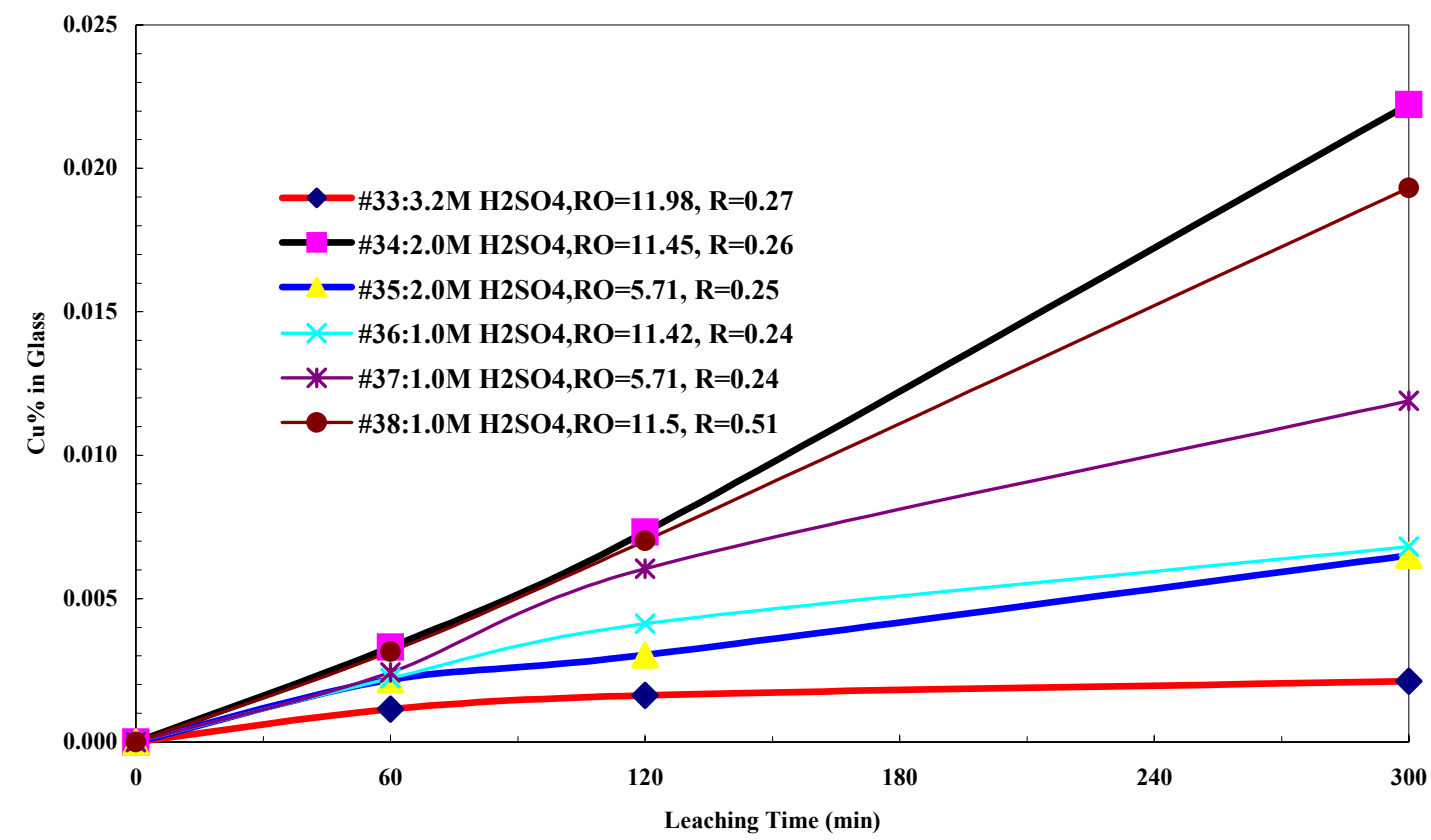

Figure 13. Cu Leaching Experiments \#33-\#38. RO-ratio of $\mathrm{H}_{2} \mathrm{O}_{2}$ to glass $(\mathrm{mL} / \mathrm{kg}) ; \mathrm{R}$. ratio of leaching solution to glass $(\mathrm{kg} / \mathrm{kg})$

The leaching rate of cadmium and tellurium was much faster than that of copper, especially in the first hour. Without exception, the concentration of copper in the leaching agent was less than $10 \%$ of that of cadmium and tellurium. Apparently, cadmium and tellurium can be selectively removed by carefully controlling leaching time, thus, preventing copper from being transferred into solution. This is an important finding because, otherwise, copper would cause problems in the following step of separating cadmium from tellurium. Surprisingly, a higher concentration of sulfuric acid did not necessarily entail a higher leaching efficiency of cadmium and tellurium, as Figures 11 and 12 demonstrate. Figure 11 shows that leaching with $3.2 \mathrm{M}$ of $\mathrm{H}_{2} \mathrm{SO}_{4}$ was the least efficient. On the other hand, $1.0 \mathrm{M}$ of $\mathrm{H}_{2} \mathrm{SO}_{4}$ was the best at leaching cadmium.

We observed, from all leaching tests, that the ratio of tellurium to cadmium in the PV module glass is less than the stoichiometric ratio of 1.135 in the CdTe molecule, which is explained by the substitution of $\mathrm{Cd}$ for $\mathrm{Cu}$ in the molecular structure. On the other hand, cadmium is also present in $\mathrm{CdCl}_{2}$ and $\mathrm{CdS}$, whereas tellurium is present only in CdTe. Based on the concentrations of cadmium and tellurium in the leaching solutions, all 
experiments had weight ratios of tellurium to cadmium between 1.0 and 1.135, and particularly, in the first 30 minutes, the leaching rate of cadmium was faster than that of tellurium. This difference can be seen from Figures 14 and 15 in the processing time range of 30 minutes to 240 minutes. Figure 14 displays the results of leaching of intact PV module glass, while Figure 15 shows those from PV module fragments.

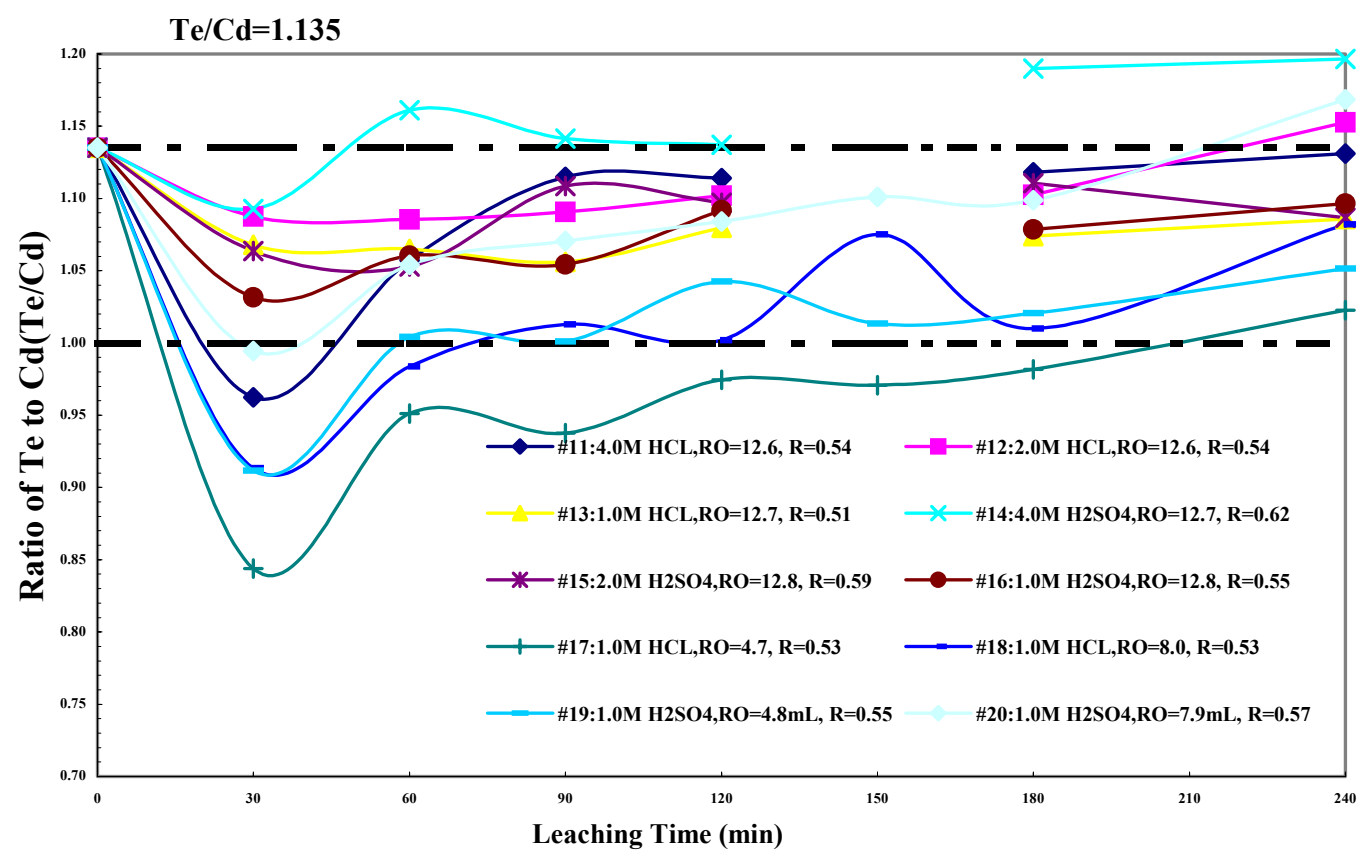

Figure 14. The ratio of Te to $\mathrm{Cd}$ in the intact $\mathrm{PV}$ module glass 


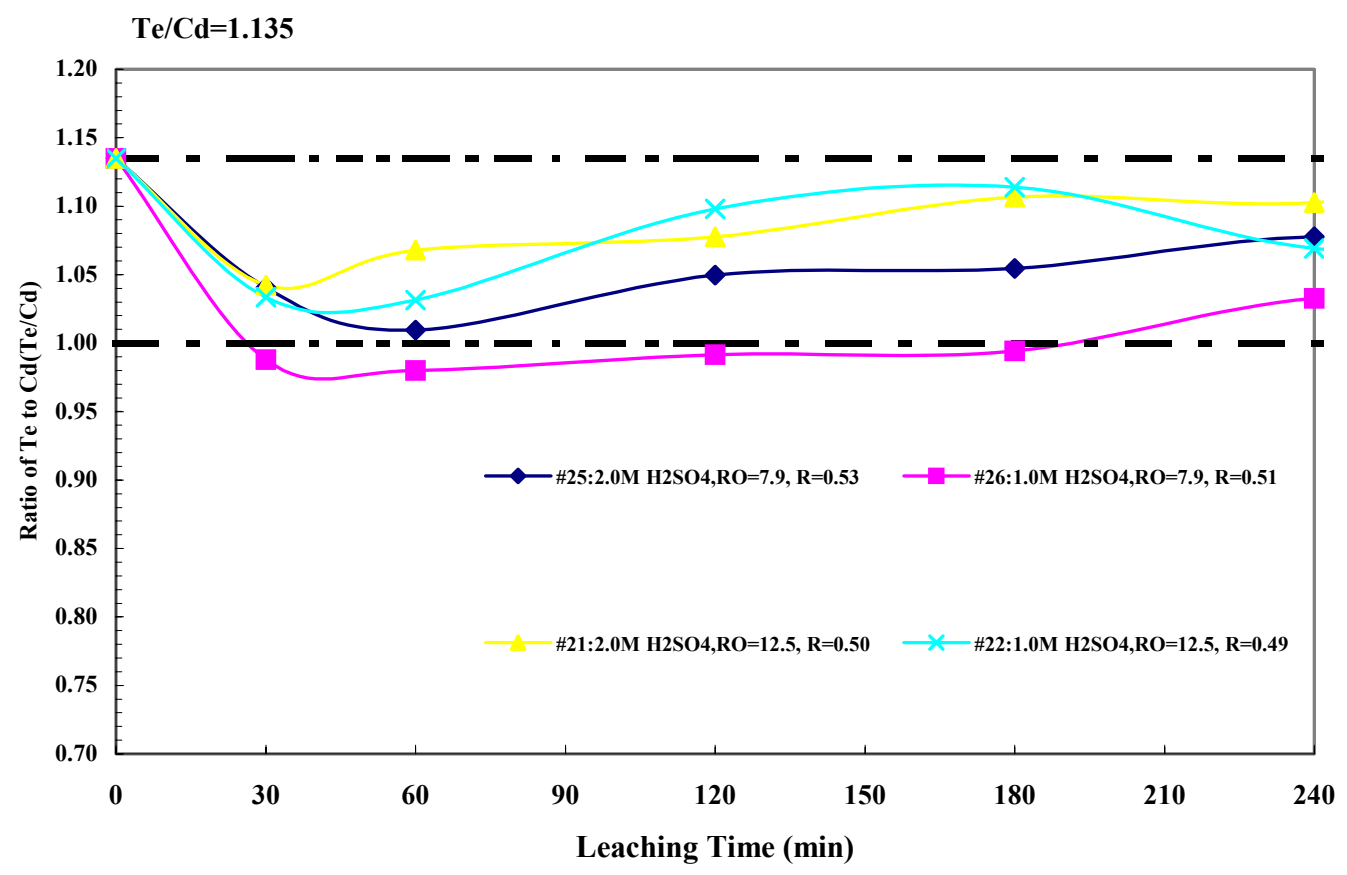

Figure 15. The ratio of Te to $\mathrm{Cd}$ in the $\mathrm{PV}$ module glass fragments

\section{UNCERTAINTY ANALYSIS}

The uncertainties considered in this experimental study relate to 1) The composition of the PV sample, 2) the composition of the leaching solution , 3) the leaching solution's weight and volume, 4) the volume of the sample taken for analysis, and, 5) the accuracy of the ICP measurements.

The PV samples were weighed before and after crushing; approximately $1 \%$ weight was lost due to fine residual or airborne particles. This loss most likely comprised glass fines produced by the impact of the hammer on the glass sheets of the PV "sandwich". The normalized data given in this report account for this $1 \%$ loss of mass.

The reported compositions of the different leaching solutions are approximate, carrying an error due to measuring volumes in graduated cylinders. However, the total weight of the solution used was accurately determined with an OHAUS (Model E0D120, accurate 
to $0.01 \mathrm{~g}$ ) scale. No quantifiable error is expected during the preparation of the leaching solution .

Samples of approximately $2 \mathrm{~mL}$ were withdrawn for analysis from a well-mixed liquid phase. They were first filtered, then their weights accurately measured with a Sartorius analytical balance (Model CP225D, accurate to 0.00001g). The measured samples were diluted with known amounts of $5 \% \mathrm{HNO}_{3}(25 \mathrm{~mL}$ with their weights measured with Sartorius analytical balance). Such measurements have an inherent uncertainty of $0.001 \%$, according to manufacturers data.

The error of the ICP analysis was determined by frequent calibration to be equal to, or less than.5\% (calibration was performed after every eighth measurements). The results of calibration are shown in Appendix B. Several measurements were repeated and the results were always reproduced within $5 \%$.

Since the above uncertainties are likely to be independent ones, , the overall uncertainty of the results is believed to be within $5 \%$.

\section{CONCLUSION and RECOMMENDATIONS}

We demonstrated that $\mathrm{Cd}$ and $\mathrm{Te}$ can be effectively leached from fragments of PV modules with a dilute solution (i.e., $1.0 \mathrm{M}$ ) of $\mathrm{H}_{2} \mathrm{SO} 4$ and $\sim 5.0 \mathrm{~mL} \mathrm{H}_{2} \mathrm{O}_{2}$ per $\mathrm{kg}$ of $\mathrm{PV}$ fragments. Using a dilute solution has obvious cost-, safety-, and waste-management advantages over the $3.2 \mathrm{M} \mathrm{H}_{2} \mathrm{SO}_{4} / 12 \mathrm{~mL} \mathrm{H}_{2} \mathrm{O}_{2}$ per kg solution currently used by First Solar, L.L.C. (FS). However, in our small-scale experiments we had to use approximately twice as much leaching solution as the FS process to obtain a sufficient volume for multiple sampling of the liquid phase.

The dilute leaching solutions were reused once with relatively small loss of efficiency; reuse for second time resulted in a $15 \%$ loss of efficiency. We added a small quantity of

oxidizer makeup solution before every reuse. Similarly, adding more acid could reduce 
the loss of leaching efficiency. A leaching solution with tellurium of $2.6 \mathrm{~g} / \mathrm{L}$ and cadmium of $2.3 \mathrm{~g} / \mathrm{L}$ was obtained by such a consecutive leaching procedure.

Under the same molar concentration, the leaching efficiency of sulfuric acid was better than that of hydrochloric acid.

Copper was incompletely leached in the experiments performed so far. The rate of copper leaching was especially limited in the first three hours. Therefore, cadmium and tellurium might be selectively removed by controlling the leaching time, thus leaving copper in the glass phase. This approach is environmentally acceptable since the concentration of copper in the module is much lower than all applicable waste classification standards, including the California TTLC. Preventing or reducing $\mathrm{Cu}$ extraction, might allow a better separation of cadmium from tellurium in the liquid phase.

In the second phase of this study we will quantitatively separate and recover all cadmium from the liquid phase. The recovery of tellurium and copper is of secondary importance, as these metals do not generate a "waste" classification.

\section{REFERENCES}

1. Tolley William K. and Palmer Glenn R., Recovering Cadmium and Tellurium From Thin-Film Photovoltaic Device Scrap. United States Bureau of Mines, Government Report, I 28.23:9588 (RI 9588), 1995.

2. Fthenakis Vasilis M., End-of-Life Management and Recycling of PV Modules, Energy Policy 28(2000) 1051-1058.

3. Vasilis M. Fthenakis and Moskowitz P.D., The Value and Feasibility of Proactive Recycling, NCPV Program Review Meeting, Sep. 8-11, 1998, Denver CO, (AIP) Conference Proceedings 462, (Editor, Al-Jassim et al.), Pp. 332-337, American Institute of Physics, Woodbury, NY, 1999.

4. Bohland John, Todd Dapkus, Kristin Kamm and Ken Smigielski, Solar Cells, Inc., Photovoltaics As Hazardous Materials; The Recycling Solution. Date? 
5. Malinowska B., Rakib M. and Durand G., Cadmium Recovery and Recycling from Chemical Bath Deposition of CdS Thin Layers, Progress in Photovoltaics: Research and Applications. 2002; 10:215-228.

6. Cooper W. Charles, Tellurium, Van Nostrand Reinhold Company, New York, 1971.

7. Chizhikov D. M., Cadmium, Pergamon Press Ltd., New York, 1966 


\begin{tabular}{|c|c|c|c|c|c|c|}
\hline \multicolumn{7}{|c|}{ APPENDIX A: SCALE OF EXPERIMENTS } \\
\hline \multirow[t]{2}{*}{ Exp. \# } & \multirow{2}{*}{$\begin{array}{l}\text { Total } \\
\text { Processing } \\
\text { Time } \\
\text { hours } \\
\end{array}$} & \multirow{2}{*}{ 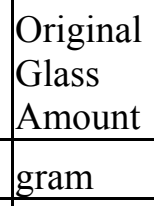 } & \multicolumn{2}{|c|}{$\begin{array}{l}\text { Original Solution } \\
\text { Amount }\end{array}$} & \multirow{2}{*}{$\begin{array}{l}\mathrm{H}_{2} \mathrm{O}_{2} \\
\text { Amount } \\
\mathrm{mL} \\
\end{array}$} & \multirow{2}{*}{\begin{tabular}{|l} 
Surfactant \\
Amount
\end{tabular}} \\
\hline & & & $\mathrm{mL}$ & gram & & \\
\hline$\# 11$ & 48 & 317.37 & 150 & 170.42 & 4.00 & 0.64 \\
\hline$\# 12$ & 48 & 317.01 & 150 & 171.11 & 4.00 & 0.64 \\
\hline$\# 13$ & 48 & 316.16 & 150 & 159.95 & 4.00 & 0.64 \\
\hline \#14 & 48 & 315.12 & 150 & 196.26 & 4.00 & 0.64 \\
\hline$\# 15$ & 48 & 313.63 & 150 & 185.00 & 4.00 & 0.64 \\
\hline$\# 16$ & 48 hours & 312.26 & 150 & 172.14 & 4.00 & 0.64 \\
\hline$\# 17$ & 24 hours & 315.99 & 150 & 167.92 & 1.50 & 0.64 \\
\hline$\# 18$ & 24 hours & 313.45 & 150 & 166.55 & 2.50 & 0.64 \\
\hline \#19 & 24 hours & 309.89 & 150 & 170.62 & 1.50 & 0.64 \\
\hline$\# 20$ & 24 hours & 314.87 & 150 & 178.97 & 2.50 & 0.64 \\
\hline$\# 21$ & 24 hours & 2153.77 & 1031 & 1066.93 & 27.00 & 4.266 \\
\hline$\# 22$ & 24 hours & 2153.99 & 1031 & 1058.89 & 27.00 & 4.266 \\
\hline$\# 23$ & 24 hours & 312.10 & 166 & 191.54 & 4.00 & none added \\
\hline$\# 24$ & 24 hours & 316.56 & 166 & 192.82 & 2.00 & None added \\
\hline$\# 25$ & 48 hours & 2154.91 & 1080 & 1152.69 & 17.00 & 4.266 \\
\hline$\# 26$ & 48 hours & 2153.76 & 1037 & 1098.51 & 17.00 & 4.266 \\
\hline$\# 27$ & 48 & 313.13 & 222 & 256.05 & 2.00 & 0.64 \\
\hline$\# 28$ & 24 & 315.70 & 73 & 86.73 & 3.78 & 0.63 \\
\hline \#29 & 24 hours & 314.80 & 74 & 81.29 & 3.61 & 0.63 \\
\hline \#30 & 24 hours & 315.40 & 72 & 78.53 & 1.80 & 0.63 \\
\hline \#31 & 24 hours & 316.31 & 74 & 76.98 & 3.61 & 0.63 \\
\hline$\# 32$ & 24 hours & 315.72 & 72 & 75.46 & 1.80 & 0.63 \\
\hline$\# 33$ & 5 hours & 315.46 & 73 & 84.09 & 3.78 & 0.63 \\
\hline \#34 & 5 hours & 315.57 & 74 & 81.63 & 3.61 & 0.63 \\
\hline \#35 & 5 hours & 315.50 & 72 & 79.77 & 1.80 & 0.63 \\
\hline$\# 36$ & 5 hours & 316.25 & 74 & 77.35 & 3.61 & 0.63 \\
\hline \#37 & 5 hours & 315.51 & 72 & 75.98 & 1.80 & 0.63 \\
\hline \#38 & 5 hours & 315.44 & 154 & 159.45 & 3.61 & 0.63 \\
\hline
\end{tabular}


Appendix B: Error of ICP analysis

\begin{tabular}{|c|c|c|c|c|c|c|c|c|}
\hline \multirow{3}{*}{$\begin{array}{l}\text { Date } \\
\text { ICP } \\
\text { Performed }\end{array}$} & \multirow[t]{3}{*}{ ICP \# } & \multicolumn{6}{|c|}{ Measurements of Standard Solutions } & \multirow{3}{*}{ Comments } \\
\hline & & \multicolumn{3}{|c|}{$\mathrm{Cd}$} & \multicolumn{3}{|c|}{$\mathrm{Te}$} & \\
\hline & & $\begin{array}{l}\text { Nominal } \\
\text { PPM }\end{array}$ & $\begin{array}{l}\text { Measured } \\
\text { PPM }\end{array}$ & $\begin{array}{l}\text { Error } \\
\%\end{array}$ & $\begin{array}{l}\text { Nominal } \\
\text { PPM }\end{array}$ & $\begin{array}{l}\text { Measured } \\
\text { PPM }\end{array}$ & $\begin{array}{l}\text { Error } \\
\%\end{array}$ & \\
\hline $12 / 05 / 03$ & 10 & $\begin{array}{c}50.00 \\
20.00 \\
20.00 \\
10.00 \\
100.00 \\
20.00 \\
0.00\end{array}$ & $\begin{array}{c}46.88 \\
19.25 \\
19.46 \\
9.83 \\
94.33 \\
19.36 \\
0.00\end{array}$ & \begin{tabular}{|c|}
-6.24 \\
-3.75 \\
-2.70 \\
-1.69 \\
-5.67 \\
-3.20 \\
$\# \# \# \# \#$
\end{tabular} & $\begin{array}{c}50.00 \\
20.00 \\
20.00 \\
10.00 \\
100.00 \\
20.00 \\
0.00\end{array}$ & $\begin{array}{c}48.89 \\
19.30 \\
19.08 \\
9.48 \\
98.42 \\
19.32 \\
0.00\end{array}$ & $\begin{array}{r}-2.22 \\
-3.50 \\
-4.60 \\
-5.16 \\
-1.58 \\
-3.40 \\
\# \# \# \# \#\end{array}$ & Cd and Te of \#11 through \#16 \\
\hline $12 / 11 / 03$ & 11 & $\begin{array}{c}50.00 \\
20.00 \\
100.00 \\
10.00 \\
100.00 \\
50.00 \\
100.00\end{array}$ & $\begin{array}{c}48.82 \\
19.30 \\
95.40 \\
9.73 \\
95.80 \\
48.26 \\
93.20\end{array}$ & $\begin{array}{l}-2.36 \\
-3.50 \\
-4.60 \\
-2.68 \\
-4.20 \\
-3.48 \\
-6.80\end{array}$ & & & & $\begin{array}{l}\text { Cd of \#11 through } \# 16 \\
\text { Glasswool of } \# 6, \# 8 \\
\text { Te was not measured }\end{array}$ \\
\hline $12 / 15 / 03$ & 12 & 50.55 & 50.56 & 0.02 & 50.60 & 50.29 & -0.61 & Glasswool of \#6, \#8 \\
\hline $12 / 16 / 03$ & 13 & $\begin{array}{c}9.93 \\
20.04 \\
39.91 \\
20.04\end{array}$ & $\begin{array}{c}9.61 \\
21.08 \\
41.75 \\
20.32\end{array}$ & $\begin{array}{l}-3.24 \\
5.19 \\
4.61 \\
1.40\end{array}$ & $\begin{array}{l}10.07 \\
20.30 \\
40.65 \\
20.30\end{array}$ & $\begin{array}{c}9.52 \\
20.85 \\
42.62 \\
20.59\end{array}$ & $\begin{array}{c}-5.51 \\
2.70 \\
4.86 \\
1.42\end{array}$ & $\mathrm{Cd}$ and $\mathrm{Te}$ of $\# 17$ through $\# 20$ \\
\hline $12 / 17 / 03$ & 14 & $\begin{array}{c}40.65 \\
9.93 \\
100.00\end{array}$ & $\begin{array}{c}40.56 \\
9.88 \\
92.12\end{array}$ & $\begin{array}{l}-0.21 \\
-0.52 \\
-7.88\end{array}$ & $\begin{array}{c}40.65 \\
10.07 \\
100.00\end{array}$ & $\begin{array}{c}41.70 \\
9.92 \\
97.76\end{array}$ & $\begin{array}{r}2.60 \\
-1.48 \\
-2.24\end{array}$ & $\begin{array}{l}\mathrm{Cd} \text { and } \mathrm{Te} \text { of } \# 11 \text { through } \# 16 \\
24 \text {-hour leaching and before } 24 \text {-hour leaching }\end{array}$ \\
\hline Date & ICP \# & & easurement & S of Stanc & lard Solut & ons & & \\
\hline $\mathrm{ICP}$ & & & $\mathrm{Cd}$ & & & $\mathrm{Te}$ & & Comments \\
\hline Performed & & $\begin{array}{l}\text { Nominal } \\
\text { PPM }\end{array}$ & $\begin{array}{l}\text { Measured } \\
\text { PPM }\end{array}$ & $\begin{array}{l}\text { Error } \\
\%\end{array}$ & $\begin{array}{l}\text { Nominal } \\
\text { PPM }\end{array}$ & $\begin{array}{l}\text { Measured } \\
\text { PPM }\end{array}$ & $\begin{array}{l}\text { Error } \\
\%\end{array}$ & \\
\hline $12 / 21 / 03$ & 15 & $\begin{array}{l}10.05 \\
19.88 \\
99.51 \\
40.17\end{array}$ & $\begin{array}{l}10.19 \\
19.76 \\
98.75 \\
40.46\end{array}$ & $\begin{array}{c}1.39 \\
-0.61 \\
-0.77 \\
0.71 \\
\end{array}$ & $\begin{array}{c}10.19 \\
20.33 \\
101.13 \\
40.83\end{array}$ & $\begin{array}{c}9.67 \\
20.09 \\
103.60 \\
40.94\end{array}$ & $\begin{array}{c}-5.02 \\
-1.18 \\
2.44 \\
0.26\end{array}$ & $\begin{array}{l}\text { Cd and Te of } \# 21 \text { and } \# 22 \\
\text { Cd and Te of } \# 11 \text { through \#16 of 48-hour leaching } \\
\text { Glasswool of } \# 5, \# 7 \text {, and \#4 }\end{array}$ \\
\hline $12 / 22 / 03$ & 16 & & & & & & & $\mathrm{Cu}$ of $\# 21$ and $\# 22$ \\
\hline $12 / 29 / 03$ & 17 & $\begin{array}{l}10.06 \\
19.80 \\
40.08 \\
19.80 \\
10.06 \\
40.08\end{array}$ & $\begin{array}{c}9.85 \\
19.00 \\
38.63 \\
20.22 \\
10.17 \\
39.61\end{array}$ & $\begin{array}{c}-2.10 \\
-4.03 \\
-3.62 \\
2.14 \\
1.12 \\
-1.17\end{array}$ & & & & $\begin{array}{l}\text { Cd and } \mathrm{Cu} \text { of \#11 through \#16 } \\
\text { of before } 24 \mathrm{hrs}, 24 \mathrm{hrs} \text {, and } 48 \mathrm{hrs} \text { results } \\
\# 17 \text { through } \# 20 \text { of } 24 \mathrm{hrs} \text { results }\end{array}$ \\
\hline $01 / 04 / 04$ & 18 & $\begin{array}{l}19.88 \\
99.51 \\
40.17 \\
19.88 \\
10.05\end{array}$ & $\begin{array}{c}19.34 \\
99.60 \\
40.67 \\
19.57 \\
9.94\end{array}$ & $\begin{array}{c}-2.73 \\
0.09 \\
1.23 \\
-1.57 \\
-1.12\end{array}$ & $\begin{array}{c}20.33 \\
101.13 \\
40.83 \\
20.33 \\
10.19\end{array}$ & $\begin{array}{c}19.61 \\
102.90 \\
40.74 \\
19.76 \\
9.86\end{array}$ & $\begin{array}{l}-3.54 \\
1.75 \\
-0.23 \\
-2.80 \\
-3.17\end{array}$ & $\begin{array}{l}\mathrm{Cd}, \mathrm{Te} \text { of } \# 23 \text { and } \# 24 \\
\mathrm{Cu} \text { was not measured }\end{array}$ \\
\hline $01 / 09 / 04$ & 19 & & & & & & & $\begin{array}{l}\mathrm{Cu} \text { of } \# 25, \# 26 \\
\mathrm{Cu} \text { of \#21 and \#22 of } 24 \mathrm{hrs} \text { plus } 48 \text {-hrs leaching }\end{array}$ \\
\hline $01 / 12 / 04$ & 20 & $\begin{array}{c}0.00 \\
99.51 \\
19.26 \\
40.17 \\
10.12\end{array}$ & $\begin{array}{c}0.01 \\
96.71 \\
19.73 \\
41.06 \\
10.15\end{array}$ & $\begin{array}{l}-2.82 \\
2.44 \\
2.21 \\
0.34\end{array}$ & $\begin{array}{c}0.00 \\
101.13 \\
19.45 \\
40.83 \\
10.15\end{array}$ & $\begin{array}{c}0.18 \\
100.80 \\
19.49 \\
41.33 \\
10.02\end{array}$ & $\begin{array}{c}-0.33 \\
0.20 \\
1.22 \\
-1.30\end{array}$ & $\begin{array}{l}\mathrm{Cd} \text { and } \mathrm{Te} \text { of } \# 25, \# 26 \\
\mathrm{Cd} \text { and } \mathrm{Te} \text { of } \# 21 \text { and } \# 22 \text { of } 24 \mathrm{hrs} \text { plus } 48 \text {-hrs leaching }\end{array}$ \\
\hline
\end{tabular}




\begin{tabular}{|c|c|c|c|c|c|c|c|c|}
\hline \multirow{3}{*}{$\begin{array}{l}\text { Date } \\
\text { ICP } \\
\text { Performed }\end{array}$} & \multirow[t]{3}{*}{ ICP \# } & \multicolumn{6}{|c|}{ Measurements of Standard Solutions } & \multirow{3}{*}{ Comments } \\
\hline & & \multicolumn{3}{|c|}{$\mathrm{Cd}$} & \multicolumn{3}{|c|}{$\mathrm{Te}$} & \\
\hline & & $\begin{array}{l}\text { Nominal } \\
\text { PPM }\end{array}$ & $\begin{array}{l}\text { Measured } \\
\text { PPM }\end{array}$ & $\begin{array}{l}\text { Error } \\
\%\end{array}$ & $\begin{array}{l}\text { Nominal } \\
\text { PPM }\end{array}$ & $\begin{array}{l}\text { Measured } \\
\text { PPM }\end{array}$ & $\begin{array}{l}\text { Error } \\
\%\end{array}$ & \\
\hline $01 / 14 / 04$ & $21(\mathrm{~B})$ & $\begin{array}{l}98.44 \\
19.26 \\
39.74 \\
98.44 \\
\end{array}$ & $\begin{array}{l}94.55 \\
18.97 \\
40.17 \\
93.46\end{array}$ & $\begin{array}{c}-3.95 \\
-1.51 \\
1.08 \\
-5.06\end{array}$ & $\begin{array}{c}100.13 \\
19.45 \\
40.62 \\
100.13\end{array}$ & $\begin{array}{l}98.66 \\
18.96 \\
39.74 \\
99.18\end{array}$ & $\begin{array}{l}-1.47 \\
-2.52 \\
-2.16 \\
-0.95\end{array}$ & $\mathrm{Cd}$ and $\mathrm{Te}$ of $\# 27$ only \\
\hline $01 / 20 / 04$ & 22 & $\begin{array}{c}9.83 \\
49.88 \\
99.13 \\
99.13 \\
\end{array}$ & $\begin{array}{c}9.83 \\
50.32 \\
97.72 \\
100.60\end{array}$ & $\begin{array}{c}0.01 \\
0.88 \\
-1.42 \\
1.48 \\
\end{array}$ & $\begin{array}{c}9.96 \\
50.71 \\
100.90 \\
100.90\end{array}$ & $\begin{array}{c}9.91 \\
50.58 \\
101.80 \\
104.80\end{array}$ & $\begin{array}{c}-0.52 \\
-0.26 \\
0.89 \\
3.87\end{array}$ & $\mathrm{Cd}, \mathrm{Te}$ and $\mathrm{Cu}$ of $\# 28$ through $\# 32$ \\
\hline $01 / 30 / 04$ & 23 & $\begin{array}{c}100.90 \\
39.61 \\
100.90 \\
39.61\end{array}$ & $\begin{array}{c}100.80 \\
39.76 \\
101.00 \\
39.93\end{array}$ & $\begin{array}{c}-0.10 \\
0.38 \\
0.10 \\
0.81\end{array}$ & $\begin{array}{c}101.10 \\
40.42 \\
101.10 \\
40.42\end{array}$ & $\begin{array}{c}99.91 \\
39.42 \\
103.50 \\
40.76\end{array}$ & $\begin{array}{l}-1.18 \\
-2.47 \\
2.37 \\
0.84\end{array}$ & $\mathrm{Cd}$ and $\mathrm{Te}$ of $\# 33$ through $\# 38$ \\
\hline
\end{tabular}


Appendix C: Lists of ICP analysis

\begin{tabular}{|c|c|c|c|c|c|c|}
\hline \multirow[t]{2}{*}{ Test \#11 } & \multicolumn{4}{|c|}{ Concentration of leaching solution } & \multirow{2}{*}{\multicolumn{2}{|c|}{ Percentage in glass }} \\
\hline & \multicolumn{2}{|c|}{ Original data } & \multicolumn{2}{|c|}{ Normalized data } & & \\
\hline \multirow{3}{*}{$\begin{array}{l}\text { Leaching } \\
\text { Time } \\
\text { Minute }\end{array}$} & \multicolumn{2}{|c|}{$4.0 \mathrm{M} \mathrm{HCL}, 4 \mathrm{~mL} \mathrm{H} 2 \mathrm{O} 2$} & \multicolumn{2}{|c|}{$4.0 \mathrm{M} \mathrm{HCL}, 4 \mathrm{~mL} \mathrm{H} 2 \mathrm{O} 2$} & \multirow{3}{*}{$\begin{array}{l}\% \\
\mathrm{Te}\end{array}$} & \multirow{3}{*}{$\begin{array}{l}\% \\
\mathrm{Cd}\end{array}$} \\
\hline & PPM & PPM & PPM & PPM & & \\
\hline & $\mathrm{Te}$ & $\mathrm{Cd}$ & $\mathrm{Te}$ & $\mathrm{Cd}$ & & \\
\hline 0 & 0.00 & 0.00 & 0.00 & 0.00 & 0.000 & 0.000 \\
\hline 30 & 798.55 & 829.87 & 798.55 & 829.87 & 0.043 & 0.045 \\
\hline 60 & 892.09 & 843.13 & 891.33 & 843.02 & 0.048 & 0.045 \\
\hline 90 & 988.61 & 885.34 & 986.28 & 884.54 & 0.053 & 0.047 \\
\hline 120 & 1007.89 & 903.49 & 1005.08 & 902.25 & 0.054 & 0.048 \\
\hline 180 & 1037.71 & 926.66 & 1033.93 & 924.67 & 0.056 & 0.050 \\
\hline 240 & 1058.85 & 934.24 & 1054.22 & 931.94 & 0.057 & 0.050 \\
\hline before 24-hour & 1389.74 & 1113.65 & 1368.94 & 1102.58 & 0.074 & 0.059 \\
\hline 1440 & 1213.45 & 1031.56 & 1202.69 & 1025.17 & 0.065 & 0.055 \\
\hline 2880 & 1146.13 & 1045.66 & 1139.76 & 1038.35 & \multicolumn{2}{|r|}{0.056} \\
\hline \multirow[t]{2}{*}{ Test \#12 } & \multicolumn{4}{|c|}{ Concentration of leaching solution } & \multirow{2}{*}{\multicolumn{2}{|c|}{ Percentage in glass }} \\
\hline & \multicolumn{2}{|c|}{ Original data } & \multicolumn{2}{|c|}{ Normalized data } & & \\
\hline Leaching & \multicolumn{2}{|c|}{$2.0 \mathrm{M} \mathrm{HCL}, 4 \mathrm{~mL} \mathrm{H} 2 \mathrm{O} 2$} & \multicolumn{2}{|c|}{$2.0 \mathrm{M} \mathrm{HCL}, 4 \mathrm{~mL} \mathrm{H} \mathrm{O} 2$} & \multirow{3}{*}{$\begin{array}{l}\% \\
\mathrm{Te}\end{array}$} & \\
\hline Time & PPM & PPM & PPM & PPM & & $\%$ \\
\hline Minute & $\mathrm{Te}$ & $\mathrm{Cd}$ & $\mathrm{Te}$ & $\mathrm{Cd}$ & & $\mathrm{Cd}$ \\
\hline 0 & 0.00 & 0.00 & 0.00 & 0.00 & 0.000 & 0.000 \\
\hline 30 & 956.58 & 879.65 & 956.58 & 879.65 & 0.052 & 0.047 \\
\hline 60 & 983.31 & 905.94 & 983.13 & 905.76 & 0.053 & 0.049 \\
\hline 90 & 1001.52 & 918.17 & 1001.08 & 917.82 & 0.054 & 0.050 \\
\hline 120 & 1005.84 & 912.51 & 1005.32 & 912.28 & 0.054 & 0.049 \\
\hline 180 & 1012.64 & 918.23 & 1011.93 & 917.85 & 0.055 & 0.050 \\
\hline 240 & 1043.23 & 903.29 & 1041.48 & 903.41 & 0.056 & 0.049 \\
\hline before 24-hour & 1326.74 & 1116.34 & 1313.35 & 1107.72 & 0.071 & 0.060 \\
\hline 1440 & 1194.26 & 1031.56 & 1187.21 & 1026.99 & 0.064 & 0.055 \\
\hline 2880 & 1121.62 & 981.46 & 1118.55 & 979.64 & 0.060 & 0.053 \\
\hline \multirow[t]{2}{*}{ Test \#13 } & \multicolumn{4}{|c|}{ Concentration of leaching solution } & \multirow{2}{*}{\multicolumn{2}{|c|}{ Percentage in glass }} \\
\hline & \multicolumn{2}{|c|}{ Original data } & Normaliz & data & & \\
\hline Leaching & $1.0 \mathrm{M} \mathrm{H}$ & $4 \mathrm{~mL} \mathrm{H} 2 \mathrm{O} 2$ & $1.0 \mathrm{M} \mathrm{HC}$ & $4 \mathrm{~mL} \mathrm{H} 2 \mathrm{O} 2$ & & \\
\hline Time & PPM & PPM & PPM & PPM & $\%$ & $\%$ \\
\hline Minute & $\mathrm{Te}$ & $\mathrm{Cd}$ & $\mathrm{Te}$ & $\mathrm{Cd}$ & $\mathrm{Te}$ & $\mathrm{Cd}$ \\
\hline 0 & 0.00 & 0.00 & 0.00 & 0.00 & 0.000 & 0.000 \\
\hline 30 & 967.04 & 905.64 & 967.04 & 905.64 & 0.049 & 0.046 \\
\hline 60 & 976.97 & 917.44 & 976.89 & 917.35 & 0.049 & 0.046 \\
\hline 90 & 979.80 & 927.82 & 979.68 & 927.58 & 0.050 & 0.047 \\
\hline 120 & 990.96 & 917.51 & 990.59 & 917.50 & 0.050 & 0.046 \\
\hline 180 & 999.33 & 930.43 & 998.71 & 930.03 & 0.051 & 0.047 \\
\hline 240 & 1007.35 & 927.11 & 1006.43 & 926.83 & 0.051 & 0.047 \\
\hline before 24-houn & 1391.86 & 1137.48 & 1373.61 & 1127.72 & 0.069 & 0.057 \\
\hline 1440 & 1203.13 & 1043.03 & 1194.80 & 1038.24 & 0.060 & 0.053 \\
\hline 2880 & 1148.62 & 1065.10 & 1143.57 & 1058.99 & 0.058 & 0.054 \\
\hline
\end{tabular}




\begin{tabular}{|c|c|c|c|c|c|c|}
\hline \multirow[t]{2}{*}{ Test \#14 } & \multicolumn{4}{|c|}{ Concentration of leaching solution } & \multirow{2}{*}{\multicolumn{2}{|c|}{ Percentage in glass }} \\
\hline & \multicolumn{2}{|l|}{ Original data } & \multicolumn{2}{|c|}{ Normalized data } & & \\
\hline \multirow{3}{*}{$\begin{array}{l}\text { Leaching } \\
\text { Time } \\
\text { Minute }\end{array}$} & \multicolumn{2}{|c|}{$4.0 \mathrm{M} \mathrm{H} 2 \mathrm{SO} 4,4 \mathrm{~mL} \mathrm{H} 2 \mathrm{O} 2$} & \multicolumn{2}{|c|}{$4.0 \mathrm{M} \mathrm{H} 2 \mathrm{SO} 4,4 \mathrm{~mL} \mathrm{H} 2 \mathrm{O} 2$} & \multirow{3}{*}{$\begin{array}{l}\% \\
\text { Te }\end{array}$} & \multirow{3}{*}{$\begin{array}{l}\% \\
\mathrm{Cd}\end{array}$} \\
\hline & PPM & PPM & PPM & PPM & & \\
\hline & $\mathrm{Te}$ & $\mathrm{Cd}$ & $\mathrm{Te}$ & $\mathrm{Cd}$ & & \\
\hline 0 & 0.00 & 0.00 & 0 & 0 & 0.000 & 0.000 \\
\hline 30 & 856.285546 & 783.6695633 & 856.29 & 783.67 & 0.053 & 0.049 \\
\hline 60 & 934.537692 & 804.5170023 & 933.91 & 804.35 & 0.058 & 0.050 \\
\hline 90 & 946.75 & 829.2757143 & 945.93 & 828.71 & 0.059 & 0.052 \\
\hline 120 & 942.084181 & 828.3921603 & 941.37 & 827.85 & 0.059 & 0.052 \\
\hline 180 & 964.786098 & 809.4885366 & 963.35 & 809.55 & 0.060 & 0.050 \\
\hline 240 & 973.255512 & 811.9606299 & 971.48 & 811.92 & 0.061 & 0.051 \\
\hline before 24-hour & 1130.49622 & 949.109352 & 1121.16 & 942.48 & 0.070 & 0.059 \\
\hline 1440 & 1057.85888 & 909.586876 & 1052.60 & 905.18 & 0.066 & 0.056 \\
\hline 2880 & 1045.61663 & 916.5166532 & 1041.14 & 911.66 & 0.065 & 0.057 \\
\hline \multirow[t]{2}{*}{ Test \#15 } & \multicolumn{4}{|c|}{ Concentration of leaching solution } & \multirow{2}{*}{\multicolumn{2}{|c|}{ Percentage in glas }} \\
\hline & \multicolumn{2}{|c|}{ Original data } & \multicolumn{2}{|c|}{ Normalized data } & & \\
\hline Leaching & \multicolumn{2}{|c|}{$2.0 \mathrm{M} \mathrm{H} 2 \mathrm{SO} 4,4 \mathrm{~mL} \mathrm{H} 2 \mathrm{O} 2$} & \multicolumn{2}{|c|}{$2.0 \mathrm{M} \mathrm{H} 2 \mathrm{SO} 4,4 \mathrm{~mL} \mathrm{H} 2 \mathrm{O} 2$} & \multirow{3}{*}{$\begin{array}{l}\% \\
\mathrm{Te}\end{array}$} & \\
\hline Time & PPM & PPM & PPM & PPM & & $\%$ \\
\hline Minute & $\mathrm{Te}$ & $\mathrm{Cd}$ & $\mathrm{Te}$ & $\mathrm{Cd}$ & & $\mathrm{Cd}$ \\
\hline 0 & 0.00 & 0.00 & 0.00 & 0.00 & 0.000 & 0.000 \\
\hline 30 & 829.14 & 779.46 & 829.14 & 779.46 & 0.049 & 0.046 \\
\hline 60 & 841.04 & 798.75 & 840.96 & 798.63 & 0.050 & 0.047 \\
\hline 90 & 894.61 & 806.53 & 893.85 & 806.31 & 0.053 & 0.048 \\
\hline 120 & 876.05 & 798.19 & 875.65 & 798.13 & 0.052 & 0.047 \\
\hline 180 & 899.99 & 809.83 & 898.98 & 809.47 & 0.053 & 0.048 \\
\hline 240 & 891.59 & 820.39 & 890.84 & 819.69 & 0.053 & 0.048 \\
\hline before 24-hour & 1134.49 & 963.66 & 1124.45 & 957.48 & 0.066 & 0.056 \\
\hline 1440 & 1047.12 & 908.42 & 1040.98 & 904.71 & 0.061 & 0.053 \\
\hline 2880 & 1009.55 & 872.76 & 1005.33 & 870.87 & \multicolumn{2}{|r|}{0.051} \\
\hline \multirow[t]{2}{*}{ Test \#16 } & \multicolumn{4}{|c|}{ Concentration of leaching solution } & & \\
\hline & \multicolumn{2}{|c|}{ Original data } & \multicolumn{2}{|c|}{ Normalized data } & Perce & in glass \\
\hline Leaching & $1.0 \mathrm{M} \mathrm{H} 2 \mathrm{SO}$ & $4,4 \mathrm{~mL} \mathrm{H} 2 \mathrm{O} 2$ & $1.0 \mathrm{M} \mathrm{H} 2$ & $4,4 \mathrm{~mL} \mathrm{H} 2 \mathrm{O} 2$ & & \\
\hline Time & PPM & PPM & PPM & PPM & $\%$ & $\%$ \\
\hline Minute & $\mathrm{Te}$ & $\mathrm{Cd}$ & $\mathrm{Te}$ & $\mathrm{Cd}$ & $\mathrm{Te}$ & $\mathrm{Cd}$ \\
\hline 0 & 0.00 & 0.00 & 0.00 & 0.00 & 0.000 & 0.000 \\
\hline 30 & 961.37 & 931.79 & 961.37 & 931.79 & 0.053 & 0.051 \\
\hline 60 & 1009.61 & 951.95 & 1009.30 & 951.82 & 0.056 & 0.052 \\
\hline 90 & 1012.61 & 960.24 & 1012.26 & 960.00 & 0.056 & 0.053 \\
\hline 120 & 1025.75 & 938.68 & 1025.14 & 938.87 & 0.057 & 0.052 \\
\hline 180 & 1020.07 & 945.19 & 1019.61 & 945.20 & 0.056 & 0.052 \\
\hline 240 & 1030.51 & 938.94 & 1029.71 & 939.15 & 0.057 & 0.052 \\
\hline before 24-hour & 1338.69 & 1153.62 & 1325.84 & 1145.45 & 0.073 & 0.063 \\
\hline 1440 & 1206.03 & 1064.76 & 1199.23 & 1060.63 & 0.066 & 0.058 \\
\hline 2880 & 1124.18 & 1040.84 & 1121.64 & 1037.96 & 0.062 & 0.057 \\
\hline
\end{tabular}




\begin{tabular}{|c|c|c|c|c|c|c|}
\hline \multirow[t]{2}{*}{ Test \#17 } & \multicolumn{4}{|c|}{ Concentration of leaching solution } & \multirow{2}{*}{\multicolumn{2}{|c|}{ Percentage in glass }} \\
\hline & \multicolumn{2}{|c|}{ Original data } & \multicolumn{2}{|c|}{ Normalized data } & & \\
\hline \multirow{3}{*}{$\begin{array}{l}\text { Leaching } \\
\text { Time } \\
\text { Minute }\end{array}$} & \multicolumn{2}{|c|}{$1.0 \mathrm{M} \mathrm{HCL}, 1.5 \mathrm{~mL} \mathrm{H} 2 \mathrm{O} 2$} & \multicolumn{2}{|c|}{$1.0 \mathrm{M} \mathrm{HCL}, 1.5 \mathrm{~mL} \mathrm{H} 2 \mathrm{O} 2$} & & \\
\hline & PPM & PPM & PPM & PPM & $\%$ & $\%$ \\
\hline & $\mathrm{Te}$ & $\mathrm{Cd}$ & $\mathrm{Te}$ & $\mathrm{Cd}$ & $\mathrm{Te}$ & $\mathrm{Cd}$ \\
\hline 0 & 0.00 & 0.00 & 0.00 & 0.00 & 0.000 & 0.000 \\
\hline 30 & 692.96 & 821.07 & 692.96 & 821.07 & 0.037 & 0.044 \\
\hline 60 & 905.34 & 951.13 & 903.88 & 950.24 & 0.048 & 0.050 \\
\hline 90 & 879.37 & 938.19 & 878.27 & 936.80 & 0.047 & 0.050 \\
\hline 120 & 903.46 & 926.82 & 901.86 & 925.51 & 0.048 & 0.049 \\
\hline 150 & 898.37 & 925.22 & 896.92 & 923.96 & 0.048 & 0.049 \\
\hline 180 & 898.00 & 914.23 & 896.56 & 913.33 & 0.048 & 0.049 \\
\hline 240 & 946.72 & 923.76 & 943.27 & 922.48 & 0.050 & 0.049 \\
\hline 1440 & 1277.91 & 982.87 & 1258.57 & 978.75 & 0.067 & 0.052 \\
\hline \multirow[t]{2}{*}{ Test \#18 } & \multicolumn{4}{|c|}{ Concentration of leaching solution } & \multirow{2}{*}{\multicolumn{2}{|c|}{ Percentage in glass }} \\
\hline & \multicolumn{2}{|c|}{ Original data } & \multicolumn{2}{|c|}{ Normalized data } & & \\
\hline Leaching & \multicolumn{2}{|c|}{$1.0 \mathrm{M} \mathrm{HCL}, 2.5 \mathrm{~mL} \mathrm{H} 2 \mathrm{O} 2$} & \multicolumn{2}{|c|}{$1.0 \mathrm{M} \mathrm{HCL}, 2.5 \mathrm{~mL} \mathrm{H} 2 \mathrm{O} 2$} & & \\
\hline Time & PPM & PPM & PPM & PPM & $\%$ & $\%$ \\
\hline Minute & $\mathrm{Te}$ & $\mathrm{Cd}$ & $\mathrm{Te}$ & $\mathrm{Cd}$ & $\mathrm{Te}$ & $\mathrm{Cd}$ \\
\hline 0 & 0.00 & 0.00 & 0.00 & 0.00 & 0.000 & 0.000 \\
\hline 30 & 807.57 & 884.03 & 807.57 & 884.03 & 0.043 & 0.047 \\
\hline 60 & 909.63 & 924.27 & 908.93 & 923.99 & 0.048 & 0.049 \\
\hline 90 & 921.32 & 909.72 & 920.45 & 908.71 & 0.049 & 0.048 \\
\hline 120 & 960.60 & 958.29 & 958.93 & 957.01 & 0.051 & 0.051 \\
\hline 150 & 978.52 & 907.95 & 976.35 & 908.05 & 0.052 & 0.048 \\
\hline 180 & 981.82 & 971.93 & 979.54 & 969.83 & 0.052 & 0.052 \\
\hline 240 & 1016.18 & 936.21 & 1012.48 & 935.58 & 0.054 & 0.050 \\
\hline 1440 & 1283.05 & 1005.26 & 1266.48 & 1001.31 & 0.067 & 0.053 \\
\hline \multirow[t]{2}{*}{ Test \#19 } & \multicolumn{4}{|c|}{ Concentration of leaching solution } & & \\
\hline & Original & & Normali & data & Perce & e in glass \\
\hline Leaching & $1.0 \mathrm{M} \mathrm{H} 2$ & $4,1.5 \mathrm{~mL} \mathrm{H} 2 \mathrm{O} 2$ & $1.0 \mathrm{M} \mathrm{H} 2$ & $4,1.5 \mathrm{~mL} \mathrm{H} 2 \mathrm{O} 2$ & & \\
\hline Time & PPM & PPM & PPM & PPM & $\%$ & $\%$ \\
\hline Minute & $\mathrm{Te}$ & $\mathrm{Cd}$ & $\mathrm{Te}$ & $\mathrm{Cd}$ & $\mathrm{Te}$ & $\mathrm{Cd}$ \\
\hline 0 & 0.00 & 0.00 & 0.00 & 0.00 & 0.000 & 0.000 \\
\hline 30 & 886.63 & 972.48 & 886.63 & 972.48 & 0.049 & 0.054 \\
\hline 60 & 1011.07 & 1006.13 & 1010.08 & 1005.86 & 0.056 & 0.055 \\
\hline 90 & 1038.03 & 1036.16 & 1036.60 & 1035.41 & 0.057 & 0.057 \\
\hline 120 & 1060.69 & 1015.90 & 1058.72 & 1015.63 & 0.058 & 0.056 \\
\hline 150 & 1077.09 & 1062.21 & 1074.59 & 1060.46 & 0.059 & 0.058 \\
\hline 180 & 1084.83 & 1061.81 & 1082.03 & 1060.08 & 0.060 & 0.058 \\
\hline 240 & 1106.22 & 1049.56 & 1102.39 & 1048.42 & 0.061 & 0.058 \\
\hline 1440 & 1382.63 & 1071.45 & 1363.33 & 1069.09 & 0.075 & 0.059 \\
\hline Test \#20 & Concentr & on of leaching so & ition & & & \\
\hline & Original & & Normali & data & Perce & e in glass \\
\hline Leaching & $1.0 \mathrm{M} \mathrm{H} 2$ & $4,2.5 \mathrm{~mL} \mathrm{H} 2 \mathrm{O} 2$ & $1.0 \mathrm{M} \mathrm{H} 2$ & $4,2.5 \mathrm{~mL} \mathrm{H} 2 \mathrm{O} 2$ & & \\
\hline Time & PPM & PPM & PPM & PPM & $\%$ & $\%$ \\
\hline Minute & $\mathrm{Te}$ & $\mathrm{Cd}$ & $\mathrm{Te}$ & $\mathrm{Cd}$ & $\mathrm{Te}$ & $\mathrm{Cd}$ \\
\hline 0 & 0.00 & 0.00 & 0.00 & 0.00 & 0.000 & 0.000 \\
\hline 30 & 820.17 & 824.88 & 820.17 & 824.88 & 0.047 & 0.047 \\
\hline 60 & 970.80 & 920.79 & 969.81 & 920.17 & 0.055 & 0.052 \\
\hline 90 & 1028.73 & 960.46 & 1026.98 & 959.31 & 0.058 & 0.055 \\
\hline 120 & 1056.47 & 973.80 & 1054.18 & 972.39 & 0.060 & 0.055 \\
\hline 150 & 1064.45 & 965.70 & 1061.95 & 964.51 & 0.060 & 0.055 \\
\hline 180 & 1076.39 & 978.71 & 1073.50 & 977.09 & 0.061 & 0.056 \\
\hline 240 & 1105.02 & 942.27 & 1101.01 & 942.08 & 0.063 & 0.054 \\
\hline 1440 & 1312.19 & 989.50 & 1298.67 & 987.14 & 0.074 & 0.056 \\
\hline
\end{tabular}




\begin{tabular}{|c|c|c|c|c|c|c|}
\hline \multirow[t]{2}{*}{ Test \#23 } & \multicolumn{4}{|c|}{ Concentration of leaching solution } & \multirow{2}{*}{\multicolumn{2}{|c|}{ Percentage in glass }} \\
\hline & \multicolumn{2}{|c|}{ Original data } & \multicolumn{2}{|c|}{ Normalized data } & & \\
\hline Leaching & \multicolumn{2}{|c|}{$1.0 \mathrm{M} \mathrm{H} 2 \mathrm{SO} 4$ first-used,4mL $\mathrm{H}$} & \multicolumn{4}{|c|}{ 1.0M H2SO4 first-used,4mL $\mathrm{H} 2 \mathrm{O} 2$} \\
\hline Time & PPM & PPM & PPM & PPM & $\%$ & $\%$ \\
\hline Minute & $\mathrm{Te}$ & $\mathrm{Cd}$ & $\mathrm{Te}$ & $\mathrm{Cd}$ & $\mathrm{Te}$ & $\mathrm{Cd}$ \\
\hline 0 & 0.00 & 0.00 & 0.00 & 0.00 & 0.000 & 0.000 \\
\hline 30 & 1904.40 & 1753.93 & 1904.40 & 1753.93 & 0.051 & 0.048 \\
\hline 60 & 1910.88 & 1754.39 & 1910.84 & 1754.39 & 0.051 & 0.048 \\
\hline 120 & 1959.95 & 1760.67 & 1959.33 & 1760.59 & 0.054 & 0.048 \\
\hline 180 & 2063.97 & 1832.15 & 2061.51 & 1830.80 & 0.060 & 0.052 \\
\hline 240 & 2109.64 & 1893.89 & 2106.09 & 1891.08 & 0.063 & 0.056 \\
\hline 300 & 1963.95 & 1769.37 & 1964.72 & 1770.25 & 0.054 & 0.049 \\
\hline 1080 & 2113.31 & 1870.56 & 2108.77 & 1867.85 & 0.063 & 0.055 \\
\hline 1440 & 2092.77 & 1896.75 & 2089.08 & 1892.95 & 0.062 & 0.056 \\
\hline starting agent & 1080.31 & 979.54 & 1080.31 & 979.54 & & \\
\hline \multirow[t]{2}{*}{ Test \#24 } & \multicolumn{4}{|c|}{ Concentration of leaching solution } & \multirow{2}{*}{\multicolumn{2}{|c|}{ Percentage in glass }} \\
\hline & Original $\mathrm{c}$ & & Normaliz & data & & \\
\hline Leaching & \multicolumn{2}{|c|}{ 1.0M H2SO4 first-used,2mL $\mathrm{H}$} & \multicolumn{4}{|c|}{ 1.0M H2SO4 first-used,2mL $\mathrm{H} 2 \mathrm{O} 2$} \\
\hline Time & PPM & PPM & PPM & PPM & $\%$ & $\%$ \\
\hline Minute & $\mathrm{Te}$ & $\mathrm{Cd}$ & $\mathrm{Te}$ & $\mathrm{Cd}$ & $\mathrm{Te}$ & $\mathrm{Cd}$ \\
\hline 0 & 0.00 & 0.00 & 0.00 & 0.00 & 0.000 & 0.000 \\
\hline 30 & 1953.20 & 1816.94 & 1953.20 & 1816.94 & 0.053 & 0.051 \\
\hline 60 & 1932.26 & 1812.98 & 1932.38 & 1813.00 & 0.052 & 0.051 \\
\hline 120 & 1998.21 & 1814.32 & 1997.59 & 1814.33 & 0.056 & 0.051 \\
\hline 180 & 1977.34 & 1747.83 & 1977.07 & 1748.96 & 0.055 & 0.047 \\
\hline 240 & 2008.16 & 1799.92 & 2007.19 & 1799.88 & 0.056 & 0.050 \\
\hline 300 & 2049.44 & 1811.83 & 2047.31 & 1811.45 & 0.059 & 0.051 \\
\hline 1080 & 2120.09 & 1829.41 & 2115.57 & 1828.44 & 0.063 & 0.052 \\
\hline 1440 & 2009.95 & 1804.55 & 2009.78 & 1804.56 & 0.057 & 0.050 \\
\hline starting agent & 1080.31 & 979.54 & 1080.31 & 979.54 & & \\
\hline
\end{tabular}




\begin{tabular}{|c|c|c|c|c|c|c|c|c|c|}
\hline \multirow[t]{2}{*}{ Test \#25 } & \multicolumn{6}{|c|}{ Concentration of leaching solution } & & & \\
\hline & \multicolumn{3}{|c|}{ Original data } & \multicolumn{3}{|c|}{ Normalized data } & \multicolumn{3}{|c|}{ Percentage in glass } \\
\hline Leaching & \multicolumn{3}{|c|}{$2.0 \mathrm{M} \mathrm{H} 2 \mathrm{SO} 4,17 \mathrm{~mL} \mathrm{H} 2 \mathrm{O} 2$} & \multicolumn{3}{|c|}{$2.0 \mathrm{M} \mathrm{H} 2 \mathrm{SO} 4,17 \mathrm{~mL} \mathrm{H} 2 \mathrm{O} 2$} & & & \\
\hline Time & PPM & PPM & PPM & PPM & PPM & PPM & $\%$ & $\%$ & $\%$ \\
\hline Minute & $\mathrm{Te}$ & $\mathrm{Cd}$ & $\mathrm{Cu}$ & $\mathrm{Te}$ & $\mathrm{Cd}$ & $\mathrm{Cu}$ & $\mathrm{Te}$ & $\mathrm{Cd}$ & $\mathrm{Cu}$ \\
\hline 0 & 0.00 & 0.00 & 0.00 & 0.00 & 0.00 & 0.00 & 0.000 & 0.000 & 0.000 \\
\hline 30 & 735.32 & 706.67 & 18.11 & 735.32 & 706.67 & 18.11 & 0.039 & 0.038 & 0.001 \\
\hline 60 & 727.91 & 721.17 & 33.42 & 727.93 & 721.12 & 33.38 & 0.039 & 0.039 & 0.002 \\
\hline 120 & 744.75 & 709.38 & 77.24 & 744.67 & 709.41 & 76.92 & 0.040 & 0.038 & 0.004 \\
\hline 180 & 753.91 & 714.69 & 136.12 & 753.74 & 714.66 & 135.24 & 0.040 & 0.038 & 0.007 \\
\hline 240 & 770.80 & 714.88 & 204.94 & 770.42 & 714.86 & 203.20 & 0.041 & 0.038 & 0.011 \\
\hline 300 & 775.49 & 727.82 & 287.19 & 775.03 & 727.59 & 284.16 & 0.041 & 0.039 & 0.015 \\
\hline 480 & 817.22 & 714.76 & 512.04 & 815.98 & 714.78 & 504.78 & 0.044 & 0.038 & 0.027 \\
\hline 1440 & 883.63 & 727.50 & 967.30 & 880.93 & 727.24 & 950.04 & 0.047 & 0.039 & 0.051 \\
\hline 2880 & 818.78 & 712.85 & 1102.44 & 817.71 & 712.96 & 1081.79 & 0.044 & 0.038 & 0.058 \\
\hline \multirow[t]{2}{*}{ Test \#26 } & \multicolumn{6}{|c|}{ Concentration of leaching solution } & \multirow{2}{*}{\multicolumn{3}{|c|}{ Percentage in glass }} \\
\hline & Original & & & Normaliz & & & & & \\
\hline Leaching & \multicolumn{3}{|c|}{$1.0 \mathrm{M} \mathrm{H} 2 \mathrm{SO} 4,17 \mathrm{~mL} \mathrm{H} 2 \mathrm{O} 2$} & \multicolumn{3}{|c|}{$1.0 \mathrm{M} \mathrm{H} 2 \mathrm{SO} 4,17 \mathrm{~mL} \mathrm{H} 2 \mathrm{O} 2$} & & & \\
\hline Time & PPM & PPM & PPM & PPM & PPM & PPM & $\%$ & $\%$ & $\%$ \\
\hline Minute & $\mathrm{Te}$ & $\mathrm{Cd}$ & $\mathrm{Cu}$ & $\mathrm{Te}$ & $\mathrm{Cd}$ & $\mathrm{Cu}$ & $\mathrm{Te}$ & $\mathrm{Cd}$ & $\mathrm{Cu}$ \\
\hline 0 & 0.00 & 0.00 & 0.00 & 0.00 & 0.00 & 0.00 & 0.000 & 0.000 & 0.000 \\
\hline 30 & 729.35 & 738.25 & 13.39 & 729.35 & 738.25 & 13.39 & 0.037 & 0.038 & 0.001 \\
\hline 60 & 758.13 & 773.61 & 26.52 & 757.98 & 773.43 & 26.45 & 0.039 & 0.039 & 0.001 \\
\hline 120 & 770.12 & 776.66 & 60.81 & 769.84 & 776.44 & 60.38 & 0.039 & 0.040 & 0.003 \\
\hline 180 & 792.14 & 796.68 & 99.47 & 791.52 & 796.15 & 98.42 & 0.040 & 0.041 & 0.005 \\
\hline 240 & 799.55 & 773.64 & 142.05 & 798.77 & 773.59 & 140.11 & 0.041 & 0.039 & 0.007 \\
\hline 300 & 814.37 & 790.71 & 190.99 & 813.20 & 790.21 & 187.76 & 0.041 & 0.040 & 0.010 \\
\hline 480 & 859.94 & 787.69 & 321.72 & 857.32 & 787.28 & 314.36 & 0.044 & 0.040 & 0.016 \\
\hline 1440 & 932.85 & 799.55 & 574.20 & 927.54 & 798.71 & 557.52 & 0.047 & 0.041 & 0.028 \\
\hline 2880 & 878.52 & 783.70 & 773.89 & 875.51 & 783.53 & 748.80 & 0.045 & 0.040 & 0.038 \\
\hline \multirow[t]{2}{*}{ Test \#27 } & \multicolumn{4}{|c|}{ Concentration of leaching solution } & \multirow{2}{*}{\multicolumn{2}{|c|}{ Percentage in glass }} & & & \\
\hline & \multicolumn{2}{|c|}{ Original data } & \multicolumn{2}{|c|}{ Normalized data } & & & & & \\
\hline Leaching & \multicolumn{2}{|c|}{$1.0 \mathrm{M} \mathrm{H} 2 \mathrm{SO} 4$ second-used, 2.0} & \multicolumn{4}{|c|}{$1.0 \mathrm{M} \mathrm{H} 2 \mathrm{SO} 4$ second-used, $2.0 \mathrm{~mL} \mathrm{H} 2 \mathrm{O} 2$} & & & \\
\hline Time & PPM & PPM & PPM & PPM & $\%$ & $\%$ & & & \\
\hline Minute & $\mathrm{Te}$ & $\mathrm{Cd}$ & $\mathrm{Te}$ & $\mathrm{Cd}$ & $\mathrm{Te}$ & $\mathrm{Cd}$ & & & \\
\hline 0 & 0.00 & 0.00 & 0.00 & 0.00 & 0.000 & 0.000 & & & \\
\hline 30 & 2598.00 & 2263.59 & 2598.00 & 2263.59 & 0.049 & 0.041 & & & \\
\hline 60 & 2582.60 & 2371.43 & 2582.73 & 2370.52 & 0.048 & 0.050 & & & \\
\hline 120 & 2607.17 & 2292.65 & 2606.88 & 2293.07 & 0.050 & 0.044 & & & \\
\hline 180 & 2571.87 & 2362.81 & 2572.48 & 2361.45 & 0.047 & 0.049 & & & \\
\hline 240 & 2577.71 & 2261.43 & 2578.12 & 2263.50 & 0.047 & 0.041 & & & \\
\hline 420 & 2545.21 & 2211.11 & 2547.00 & 2215.31 & 0.045 & 0.037 & & & \\
\hline 1440 & 2537.47 & 2219.02 & 2539.65 & 2222.82 & 0.044 & 0.038 & & & \\
\hline 2880 & 2680.72 & 2325.44 & 2674.41 & 2322.94 & 0.055 & 0.046 & & & \\
\hline starting agent & 1998.84 & 1759.63 & 1998.84 & 1759.63 & & & & & \\
\hline
\end{tabular}




\begin{tabular}{|c|c|c|c|c|c|c|c|c|c|}
\hline Test \#28 & \multicolumn{3}{|c|}{ Original data } & \multicolumn{3}{|c|}{ \#28 Normalized Results } & \multicolumn{3}{|c|}{ Percentage in glass } \\
\hline Leaching & \multicolumn{3}{|c|}{$3.2 \mathrm{M} \mathrm{H} 2 \mathrm{SO} 4,3.78 \mathrm{~mL} \mathrm{H} 2 \mathrm{O} 2$} & \multicolumn{3}{|c|}{$3.2 \mathrm{M} \mathrm{H} 2 \mathrm{SO} 4,3.78 \mathrm{~mL} \mathrm{H} 2 \mathrm{O} 2$} & \multirow{3}{*}{$\begin{array}{l}\% \\
\mathrm{Te}\end{array}$} & \multirow{3}{*}{$\begin{array}{l}\% \\
\mathrm{Cd}\end{array}$} & \multirow{3}{*}{$\begin{array}{l}\% \\
\mathrm{Cu}\end{array}$} \\
\hline Time & PPM & PPM & PPM & PPM & PPM & PPM & & & \\
\hline Minute & $\mathrm{Te}$ & $\mathrm{Cd}$ & $\mathrm{Cu}$ & $\mathrm{Te}$ & $\mathrm{Cd}$ & $\mathrm{Cu}$ & & & \\
\hline 0 & 0.00 & 0.00 & 0.00 & 0.00 & 0.00 & 0.00 & 0.000 & 0.000 & 0.000 \\
\hline 300 & 1495.56 & 1343.76 & 730.62 & 1495.56 & 1343.76 & 730.62 & 0.041 & 0.037 & 0.020 \\
\hline 600 & 1500.62 & 1323.08 & 1388.20 & 1500.49 & 1323.61 & 1371.32 & 0.041 & 0.036 & 0.038 \\
\hline 1440 & 1509.20 & 1320.88 & 1711.38 & 1508.63 & 1321.52 & 1677.90 & 0.041 & 0.036 & 0.046 \\
\hline Test \#29 & \multicolumn{3}{|c|}{ Original data } & \multicolumn{3}{|c|}{ \#29 Normalized Results } & \multicolumn{3}{|c|}{ Percentage in glass } \\
\hline Leaching & \multicolumn{3}{|c|}{$2.0 \mathrm{M} \mathrm{H} 2 \mathrm{SO} 4,3.613 \mathrm{~mL} \mathrm{H} 2 \mathrm{O} 2$} & \multicolumn{3}{|c|}{ 2.0M H2SO4,3.613mL H2O2 } & & & \\
\hline Time & PPM & PPM & PPM & PPM & PPM & PPM & $\%$ & $\%$ & $\%$ \\
\hline Minute & $\mathrm{Te}$ & $\mathrm{Cd}$ & $\mathrm{Cu}$ & $\mathrm{Te}$ & $\mathrm{Cd}$ & $\mathrm{Cu}$ & $\mathrm{Te}$ & $\mathrm{Cd}$ & $\mathrm{Cu}$ \\
\hline 0 & 0.00 & 0.00 & 0.00 & 0.00 & 0.00 & 0.00 & 0.000 & 0.000 & 0.000 \\
\hline 300 & 1605.28 & 1497.72 & 263.09 & 1605.28 & 1497.72 & 263.09 & 0.041 & 0.039 & 0.007 \\
\hline 600 & 1620.88 & 1496.54 & 306.83 & 1620.48 & 1496.57 & 305.71 & 0.042 & 0.039 & 0.008 \\
\hline 1440 & 1619.22 & 1472.90 & 364.98 & 1618.91 & 1474.13 & 360.91 & 0.042 & 0.038 & 0.009 \\
\hline Test \#30 & \multicolumn{3}{|c|}{ Original data } & \multicolumn{3}{|c|}{ \#30 Normalized Results } & \multicolumn{3}{|c|}{ Percentage in glass } \\
\hline Leaching & \multicolumn{3}{|c|}{$2.0 \mathrm{M} \mathrm{H} 2 \mathrm{SO} 4,1.8 \mathrm{~mL} \mathrm{H} 2 \mathrm{O} 2$} & \multicolumn{3}{|c|}{$2.0 \mathrm{M} \mathrm{H} 2 \mathrm{SO} 4,1.8 \mathrm{~mL} \mathrm{H} 2 \mathrm{O} 2$} & & & \\
\hline Time & PPM & PPM & PPM & PPM & PPM & PPM & $\%$ & $\%$ & $\%$ \\
\hline Minute & $\mathrm{Te}$ & $\mathrm{Cd}$ & $\mathrm{Cu}$ & $\mathrm{Te}$ & $\mathrm{Cd}$ & $\mathrm{Cu}$ & $\mathrm{Te}$ & $\mathrm{Cd}$ & $\mathrm{Cu}$ \\
\hline 0 & 0.00 & 0.00 & 0.00 & 0.00 & 0.00 & 0.00 & 0.000 & 0.000 & 0.000 \\
\hline 300 & 1705.03 & 1631.52 & 109.30 & 1705.03 & 1631.52 & 109.30 & 0.042 & 0.041 & 0.003 \\
\hline 600 & 1736.00 & 1641.68 & 128.38 & 1735.18 & 1641.41 & 127.88 & 0.043 & 0.041 & 0.003 \\
\hline 1440 & 1773.58 & 1623.24 & 136.27 & 1770.78 & 1623.95 & 135.36 & 0.044 & 0.040 & 0.003 \\
\hline Test \#31 & \multicolumn{3}{|c|}{ Original data } & \multicolumn{3}{|c|}{ \#31 Normalized Results } & \multicolumn{3}{|c|}{ Percentage in glass } \\
\hline Leaching & \multicolumn{3}{|c|}{$1.0 \mathrm{M} \mathrm{H} 2 \mathrm{SO} 4,3.613 \mathrm{~mL} \mathrm{H} 2 \mathrm{O} 2$} & \multicolumn{3}{|c|}{$1.0 \mathrm{M} \mathrm{H} 2 \mathrm{SO} 4,3.613 \mathrm{~mL} \mathrm{H} 2 \mathrm{O} 2$} & & & \\
\hline Time & PРM & PPM & PPM & PPM & PPM & PPM & $\%$ & $\%$ & $\%$ \\
\hline Minute & $\mathrm{Te}$ & $\mathrm{Cd}$ & $\mathrm{Cu}$ & $\mathrm{Te}$ & $\mathrm{Cd}$ & $\mathrm{Cu}$ & $\mathrm{Te}$ & $\mathrm{Cd}$ & $\mathrm{Cu}$ \\
\hline 0 & 0.00 & 0.00 & 0.00 & 0.00 & 0.00 & 0.00 & 0.000 & 0.000 & 0.000 \\
\hline 300 & 1572.40 & 1566.20 & 1278.77 & 1572.40 & 1566.20 & 1278.77 & 0.038 & 0.038 & 0.031 \\
\hline 600 & 1531.45 & 1586.80 & 1481.06 & 1532.52 & 1586.26 & 1475.78 & 0.037 & 0.039 & 0.036 \\
\hline 1440 & 1544.11 & 1598.96 & 1571.66 & 1544.52 & 1597.79 & 1561.65 & 0.038 & 0.039 & 0.038 \\
\hline Test \#32 & \multicolumn{3}{|c|}{ Original data } & \#32 Norm & Results & & Percen & in glas & \\
\hline Leaching & $1.0 \mathrm{M} \mathrm{H} 2$ & $\overline{4,1.80 \mathrm{~mL}}$ & & $1.0 \mathrm{M} \mathrm{H} 2 \mathrm{~s}$ & $30 \mathrm{~mL} \mathrm{H2}$ & & & & \\
\hline Time & PPM & PPM & PPM & PPM & PPM & PPM & $\%$ & $\%$ & $\%$ \\
\hline Minute & $\mathrm{Te}$ & $\mathrm{Cd}$ & $\mathrm{Cu}$ & $\mathrm{Te}$ & $\mathrm{Cd}$ & $\mathrm{Cu}$ & $\mathrm{Te}$ & $\mathrm{Cd}$ & $\mathrm{Cu}$ \\
\hline 0 & 0.00 & 0.00 & 0.00 & 0.00 & 0.00 & 0.00 & 0.000 & 0.000 & 0.000 \\
\hline 300 & 1513.69 & 1517.92 & 422.08 & 1513.69 & 1517.92 & 422.08 & 0.036 & 0.036 & 0.010 \\
\hline 600 & 1558.66 & 1504.75 & 651.88 & 1557.50 & 1505.09 & 645.95 & 0.037 & 0.036 & 0.015 \\
\hline 1440 & 1572.32 & 1499.78 & 774.61 & 1570.45 & 1500.38 & 762.33 & 0.038 & 0.036 & 0.018 \\
\hline
\end{tabular}




\begin{tabular}{|c|c|c|c|c|c|c|c|c|c|}
\hline Test \#33 & \multicolumn{3}{|c|}{ Original data } & \multicolumn{3}{|c|}{ \#33 Normalized Results } & \multicolumn{3}{|c|}{ Percentage in glass } \\
\hline Leaching & \multicolumn{3}{|c|}{$3.2 \mathrm{M} \mathrm{H} 2 \mathrm{SO} 4,3.78 \mathrm{~mL} \mathrm{H} 2 \mathrm{O} 2$} & \multicolumn{3}{|c|}{$3.2 \mathrm{M} \mathrm{H} 2 \mathrm{SO} 4,3.78 \mathrm{~mL} \mathrm{H} 2 \mathrm{O} 2$} & \multirow{3}{*}{$\%$} & \multirow[b]{2}{*}{$\%$} & \multirow{3}{*}{$\begin{array}{l}\% \\
\mathrm{Cu}\end{array}$} \\
\hline Time & PPM & PPM & PPM & PPM & PPM & PPM & & & \\
\hline Minute & $\mathrm{Te}$ & $\mathrm{Cd}$ & $\mathrm{Cu}$ & $\mathrm{Te}$ & $\mathrm{Cd}$ & $\mathrm{Cu}$ & & $\mathrm{Cd}$ & \\
\hline 0 & 0.00 & 0.00 & 0.00 & 0.00 & 0.00 & 0.00 & 0.000 & 0.000 & 0.000 \\
\hline 60 & 1598.15 & 1427.25 & 42.94 & 1598.15 & 1427.25 & 42.94 & 0.043 & 0.038 & 0.001 \\
\hline 120 & 1625.06 & 1419.31 & 61.84 & 1623.99 & 1419.62 & 61.09 & 0.043 & 0.038 & 0.002 \\
\hline 300 & 1665.19 & 1424.38 & 82.04 & 1660.95 & 1424.29 & 79.69 & 0.044 & 0.038 & 0.002 \\
\hline Test \#34 & \multicolumn{3}{|c|}{ Original data } & \multicolumn{3}{|c|}{ \#34 Normalized Results } & \multicolumn{3}{|c|}{ Percentage in glass } \\
\hline Leaching & \multicolumn{3}{|c|}{$2.0 \mathrm{M} \mathrm{H} 2 \mathrm{SO} 4,3.613 \mathrm{~mL} \mathrm{H} 2 \mathrm{O} 2$} & \multicolumn{3}{|c|}{$2.0 \mathrm{M} \mathrm{H} 2 \mathrm{SO} 4,3.613 \mathrm{~mL} \mathrm{H} 2 \mathrm{O} 2$} & & & \\
\hline Time & PРM & PPM & PPM & PPM & PPM & PPM & $\%$ & $\%$ & $\%$ \\
\hline Minute & $\mathrm{Te}$ & $\mathrm{Cd}$ & $\mathrm{Cu}$ & $\mathrm{Te}$ & $\mathrm{Cd}$ & $\mathrm{Cu}$ & $\mathrm{Te}$ & $\mathrm{Cd}$ & $\mathrm{Cu}$ \\
\hline 0 & 0.00 & 0.00 & 0.00 & 0.00 & 0.00 & 0.00 & 0.000 & 0.000 & 0.000 \\
\hline 60 & 1456.06 & 1388.29 & 127.93 & 1456.06 & 1388.29 & 127.93 & 0.038 & 0.036 & 0.003 \\
\hline 120 & 1490.65 & 1403.22 & 287.66 & 1489.69 & 1402.80 & 283.21 & 0.039 & 0.036 & 0.007 \\
\hline 300 & 1521.93 & 1387.11 & 897.33 & 1519.23 & 1387.59 & 858.92 & 0.039 & 0.036 & 0.022 \\
\hline Test \#35 & \multicolumn{3}{|c|}{ Original data } & \multicolumn{3}{|c|}{ \#35 Normalized Results } & \multicolumn{3}{|c|}{ Percentage in glass } \\
\hline Leaching & \multicolumn{3}{|c|}{$2.0 \mathrm{M} \mathrm{H} 2 \mathrm{SO} 4,1.8 \mathrm{~mL} \mathrm{H} 2 \mathrm{O} 2$} & \multicolumn{3}{|c|}{$2.0 \mathrm{M} \mathrm{H} 2 \mathrm{SO} 4,1.8 \mathrm{~mL} \mathrm{H} 2 \mathrm{O} 2$} & & & \\
\hline Time & PPM & PPM & PPM & PPM & PPM & PPM & $\%$ & $\%$ & $\%$ \\
\hline Minute & $\mathrm{Te}$ & $\mathrm{Cd}$ & $\mathrm{Cu}$ & $\mathrm{Te}$ & $\mathrm{Cd}$ & $\mathrm{Cu}$ & $\mathrm{Te}$ & $\mathrm{Cd}$ & $\mathrm{Cu}$ \\
\hline 0 & 0.00 & 0.00 & 0.00 & 0.00 & 0.00 & 0.00 & 0.000 & 0.000 & 0.000 \\
\hline 60 & 1698.46 & 1634.01 & 86.20 & 1698.46 & 1634.01 & 86.20 & 0.043 & 0.041 & 0.002 \\
\hline 120 & 1738.74 & 1655.34 & 121.18 & 1737.39 & 1654.62 & 120.01 & 0.044 & 0.042 & 0.003 \\
\hline 300 & 1842.76 & 1689.93 & 268.23 & 1834.45 & 1686.90 & 257.21 & 0.046 & 0.043 & 0.007 \\
\hline Test \#36 & \multicolumn{3}{|c|}{ Original data } & \multicolumn{3}{|c|}{ \#36 Normalized Results } & Percen & e in glas & \\
\hline Leaching & $1.0 \mathrm{M} \mathrm{H} 2 \mathrm{~s}$ & $4,3.613 \mathrm{~m}$ & & $1.0 \mathrm{M} \mathrm{H} 2$ & $613 \mathrm{~mL} \mathrm{H}$ & & & & \\
\hline Time & PPM & PPM & PPM & PPM & PPM & PPM & $\%$ & $\%$ & $\%$ \\
\hline Minute & $\mathrm{Te}$ & $\mathrm{Cd}$ & $\mathrm{Cu}$ & $\mathrm{Te}$ & $\mathrm{Cd}$ & $\mathrm{Cu}$ & $\mathrm{Te}$ & $\mathrm{Cd}$ & $\mathrm{Cu}$ \\
\hline 0 & 0.00 & 0.00 & 0.00 & 0.00 & 0.00 & 0.00 & 0.000 & 0.000 & 0.000 \\
\hline 60 & 1779.96 & 1698.10 & 90.74 & 1779.96 & 1698.10 & 90.74 & 0.044 & 0.042 & 0.002 \\
\hline 120 & 1841.91 & 1714.27 & 171.48 & 1839.80 & 1713.72 & 168.72 & 0.045 & 0.042 & 0.004 \\
\hline 300 & 1899.14 & 1717.76 & 289.36 & 1893.12 & 1716.97 & 278.56 & 0.046 & 0.042 & 0.007 \\
\hline Test \#37 & Original & & & \#37 Norn & Results & & Percen & in glas & \\
\hline Leaching & $1.0 \mathrm{M} \mathrm{H} 2 \mathrm{~s}$ & $4,1.80 \mathrm{~mL}$ & & $1.0 \mathrm{M} \mathrm{H} 2$ & $80 \mathrm{~mL} \mathrm{H2}$ & & & & \\
\hline Time & PPM & PPM & PPM & PPM & PPM & PPM & $\%$ & $\%$ & $\%$ \\
\hline Minute & $\mathrm{Te}$ & $\mathrm{Cd}$ & $\mathrm{Cu}$ & $\mathrm{Te}$ & $\mathrm{Cd}$ & $\mathrm{Cu}$ & $\mathrm{Te}$ & $\mathrm{Cd}$ & $\mathrm{Cu}$ \\
\hline 0 & 0.00 & 0.00 & 0.00 & 0.00 & 0.00 & 0.00 & 0.000 & 0.000 & 0.000 \\
\hline 60 & 1779.21 & 1716.01 & 100.64 & 1779.21 & 1716.01 & 100.64 & 0.043 & 0.041 & 0.002 \\
\hline 120 & 1871.27 & 1772.74 & 255.52 & 1868.70 & 1771.16 & 251.20 & 0.045 & 0.043 & 0.006 \\
\hline 300 & 1914.06 & 1696.61 & 512.54 & 1909.11 & 1699.27 & 493.88 & 0.046 & 0.041 & 0.012 \\
\hline Test \#38 & Original c & & & \#38 Norn & Results & & Percen & in glas & \\
\hline Leaching & $1.0 \mathrm{M} \mathrm{H} 2$ & $4,3.613 \mathrm{~m}$ & & $1.0 \mathrm{M} \mathrm{H} 2$ & $\overline{613 \mathrm{~mL} \mathrm{H}}$ & & & & \\
\hline Time & PPM & PPM & PPM & PPM & PPM & PPM & $\%$ & $\%$ & $\%$ \\
\hline Minute & $\mathrm{Te}$ & $\mathrm{Cd}$ & $\mathrm{Cu}$ & $\mathrm{Te}$ & $\mathrm{Cd}$ & $\mathrm{Cu}$ & $\mathrm{Te}$ & $\mathrm{Cd}$ & $\mathrm{Cu}$ \\
\hline 0 & 0.00 & 0.00 & 0.00 & 0.00 & 0.00 & 0.00 & 0.000 & 0.000 & 0.000 \\
\hline 60 & 821.56 & 800.41 & 62.45 & 821.56 & 800.41 & 62.45 & 0.042 & 0.040 & 0.003 \\
\hline 120 & 851.17 & 807.13 & 139.80 & 850.78 & 807.04 & 138.80 & 0.043 & 0.041 & 0.007 \\
\hline 300 & 913.86 & 839.22 & 389.63 & 911.85 & 838.30 & 382.14 & 0.046 & 0.042 & 0.019 \\
\hline
\end{tabular}

